\title{
Application of Remote Sensing Data to Constrain Operational Rainfall-Driven Flood Forecasting: A Review
}

\author{
Yuan Li *, Stefania Grimaldi, Jeffrey P. Walker and Valentijn R. N. Pauwels \\ Department of Civil Engineering, Monash University, Clayton, Victoria 3800, Australia; \\ stefania.grimaldi@monash.edu (S.G.); jeff.walker@monash.edu (J.P.W.); \\ valentijn.pauwels@monash.edu (V.R.N.P.) \\ * Correspondence: yuan.li2@monash.edu; Tel.: +61-3-9905-4952
}

Academic Editors: Richard Gloaguen and Prasad S. Thenkabail

Received: 5 April 2016; Accepted: 23 May 2016; Published: 28 May 2016

\begin{abstract}
Fluvial flooding is one of the most catastrophic natural disasters threatening people's lives and possessions. Flood forecasting systems, which simulate runoff generation and propagation processes, provide information to support flood warning delivery and emergency response. The forecasting models need to be driven by input data and further constrained by historical and real-time observations using batch calibration and/or data assimilation techniques so as to produce relatively accurate and reliable flow forecasts. Traditionally, flood forecasting models are forced, calibrated and updated using in-situ measurements, e.g., gauged precipitation and discharge. The rapid development of hydrologic remote sensing offers a potential to provide additional/alternative forcing and constraint to facilitate timely and reliable forecasts. This has brought increasing interest to exploring the use of remote sensing data for flood forecasting. This paper reviews the recent advances on integration of remotely sensed precipitation and soil moisture with rainfall-runoff models for rainfall-driven flood forecasting. Scientific and operational challenges on the effective and optimal integration of remote sensing data into forecasting models are discussed.
\end{abstract}

Keywords: remote sensing; flood forecasting; soil moisture; precipitation; batch calibration; data assimilation

\section{Introduction}

Floods are among the most destructive natural disasters, threatening lives as well as properties. Generally, fluvial floods are formed in the following series of processes: runoff generation, runoff concentration, streamflow propagation and floodplain inundation [1,2]. Most operational fluvial flood forecasting systems only simulate the first three processes, to provide water level and streamflow forecasts [3]. The three processes are typically simulated through coupled rainfall/snowmelt-runoff models and hydrological routing models [3-9]. Only few systems incorporate more sophisticated hydraulic models to assist streamflow propagation simulation which allows the forecasting of floodplain inundation as well [10]. The forecasted water level and streamflow information is finally used to produce timely flood warnings, and improve the emergency preparedness [1].

With the aim being to estimate future flow amounts at critical points in a river network, streamflow forecasting systems can be divided into two types: short-term forecasting with a lead time of hours to weeks [2], and long-term/seasonal forecasting with a lead time of months to years [11]. The short-term forecasting systems are usually adopted for flood management, e.g., flood warning and flood-related dam system control, whilst the long-term forecasting systems are used for long-term water resource management, e.g., drought prediction, irrigation scheduling, and water allocation under changing 
climate. From this perspective, flood forecasting systems belong to short-term streamflow forecasting, therefore confining the scope of this review.

Rainfall-runoff models, which simulate the rainfall infiltration and runoff generation followed by streamflow concentration and propagation processes, form the core of a rainfall-driven flood forecasting system [12]. These models are all driven by data to different extents [8]. Firstly, these models are not purely self-feedback and thus require to be forced by measurements of input variables such as precipitation and potential evapotranspiration (PET). Secondly, suffering from various sources of uncertainties, they need to be further constrained by observations of variables such as discharge and soil moisture, through batch calibration (parameter estimation) and/or data assimilation (real-time updating) [1]. Operational forecasting systems typically adopt all accessible in-situ data, such as ground-based precipitation and PET as forcing and gauged discharge for calibration/updating. However, in order to produce the most accurate and reliable forecasts, it is likely that rainfall-runoff models have reached an effectiveness limit which cannot be exceeded without incorporating new types of data [13]. Fortuitously, the developments of remote sensing techniques provide additional information to further constrain the forecasting systems.

Numerous studies have been conducted in the recent couple of decades on using remote sensing data to constrain flood forecasting. While a number of reviews on hydrologic model data integration [14-19] and the use of remote sensing data for flood monitoring and mapping [20,21] have referred to this topic; there has not been a review article specifically on the use of remote sensing in operational flood forecasting applications, which is an important research area and has its own specific challenges and opportunities. Although floods can be driven by either rainfall or snowmelt, these types of processes are quite different in runoff generation mechanism. Considering the scope and deepness, this paper will only focus on rainfall-driven floods. Section 2 of this article introduces the background of remote sensing constrained flood forecasting from different perspectives. Sections 3 and 4 give a review on recent research that has used remote sensing derived precipitation and soil moisture products for flood forecasting, respectively. Related scientific and operational problems, as well as future directions, are discussed in Sections 3 and 4 followed by the conclusion in Section 5 .

\section{Background on Remote Sensing Constrained Flood Forecasting}

Studies or applications focusing on use of remote sensing data for flood forecasting can be viewed or classified from different perspectives, including the type of remote sensing observations, the hydrologic models, the approaches to integrate the models and observations, as well as the uncertainties addressed (Figure 1).

Remotely sensed precipitation, soil moisture and snow cover (or water equivalent) are three common remote sensing products implemented as constraint in hydrologic forecasting. Precipitation products are generally utilized to remedy the insufficient gauged rainfall information [22], e.g., the ungauged areas, while soil moisture and snow products are commonly used to improve the key storage variables in rainfall-runoff and snowmelt-runoff models [15], respectively, so as to improve streamflow forecasts. There have also been attempts to integrate other types of remote sensing products into forecasting models, e.g., remotely sensed terrestrial water storage (TWS) [16,23], leaf area index (LAI) and/or evapotranspiration (ET) [18]; however, they have not been used for operational purposes. Remote sensing based elevation data have been used in hydraulic modelling, which mostly focus on flood management instead of operational forecasting at the current stage [20,21].

From the perspective of forecasting models, there are three types of hydrologic models: data-based (empirical), conceptual, and process-based models. The feasibility, effectiveness and efficiency of data-model fusing schemes differ according to the different types of models used, their different levels of complexity, and their representativeness of physical processes. For instance, despite the high efficiency of data-based models, remote sensing products such as soil moisture often cannot be directly used as a constraint, as there may be no comparable variables in the model. A highly process-based distributed model may be better suited to incorporate remote sensing products, but they 
have not been widely used for operational forecasting due to the high computational demand and extensive data demands. Simple conceptual models have been preferred in operational applications, but challenges also exist in matching remote sensing data and model variables with vague physical meaning. For detailed background in modelling techniques in flood forecasting, it is recommended to refer to Sene [1] and Emerton et al. [3].

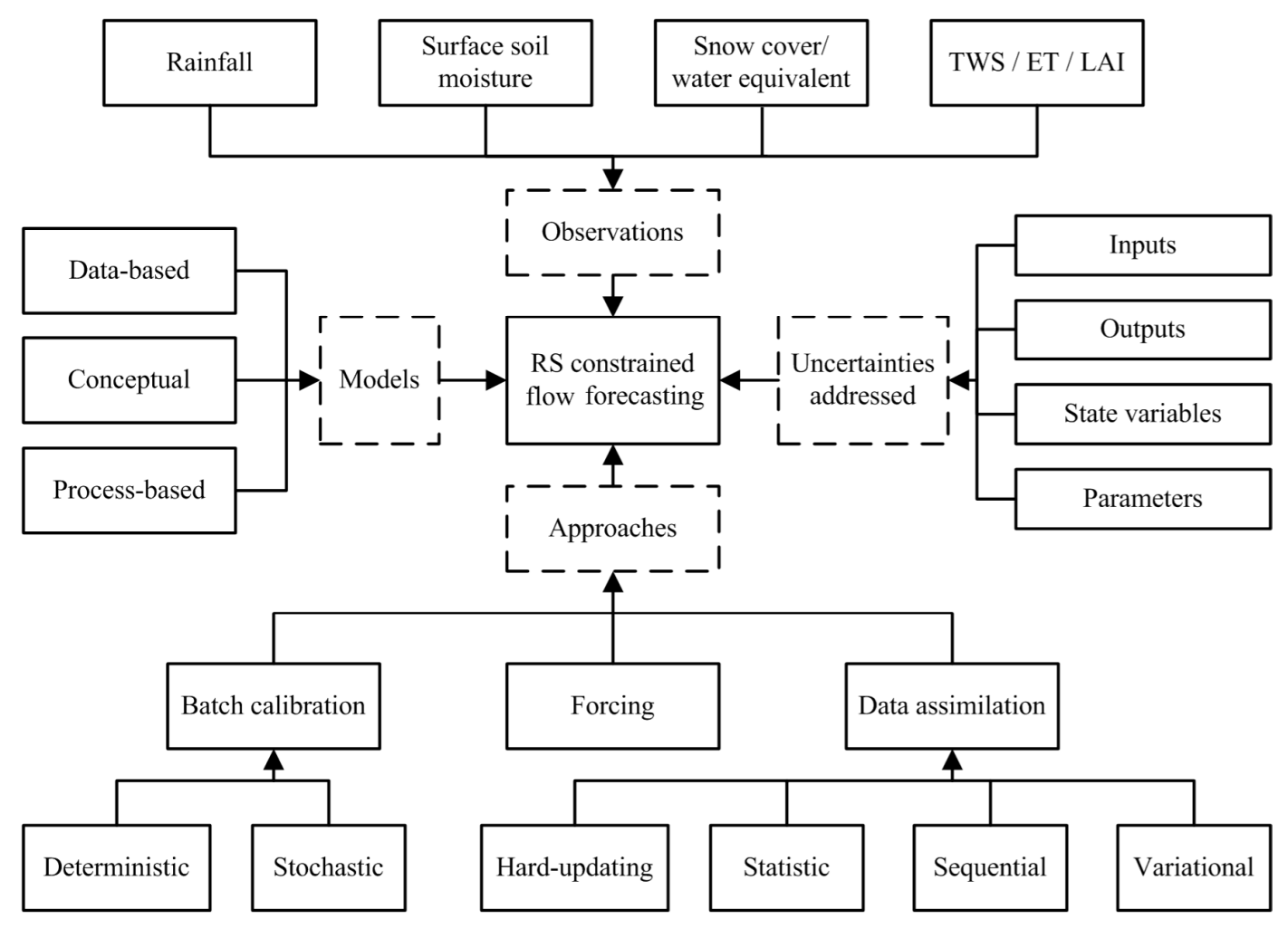

Figure 1. Overview of remote sensing constrained flood forecasting systems.

According to the approaches of combining models and data, the applications/studies can be classified into direct forcing, batch calibration and data assimilation. Remote sensing derived forcing variables (e.g., precipitation) can be used to drive the hydrologic models. Remotely sensed variables such as soil moisture can be used to address long-term systematic errors through batch calibration and short-term random errors through data assimilation. The batch calibration methods can be further classified into deterministic calibration [24-26] and stochastic calibration [27-29], while the data assimilation algorithms can be further classified into hard updating (direct insertion or initialization), statistical correction, nudging, sequential assimilation, and variational assimilation [15,30-32]. Related to those data-model fusing approaches, remote sensing data can be used to address uncertainties in different sources, including input data, output data, state variables, and model parameters [1]. Batch calibration is used to address systematic uncertainty in model parameters. Statistical correction is typically implemented to directly correct errors in output variables. Other data assimilation strategies, including hard updating, sequential and variational assimilation, are normally applied to reduce short-term errors in state variables; nevertheless, more advanced updating approaches can also be extended for updating input variables and/or parameters by treating them as state variables [15]. Figure 2 illustrate a schematic of the batch calibration, the extended Kalman filter, and the ensemble Kalman filter as examples of data-model integration. For a detailed background in batch calibration and data assimilation techniques, we refer to Moradkhani and Sorooshian [33].

Although various remote sensing products, hydrologic models, and integration approaches can be used, the implementation of remote sensing data to constrain streamflow forecasting is under-researched and great opportunities and improvements are expected in future studies [15]. 

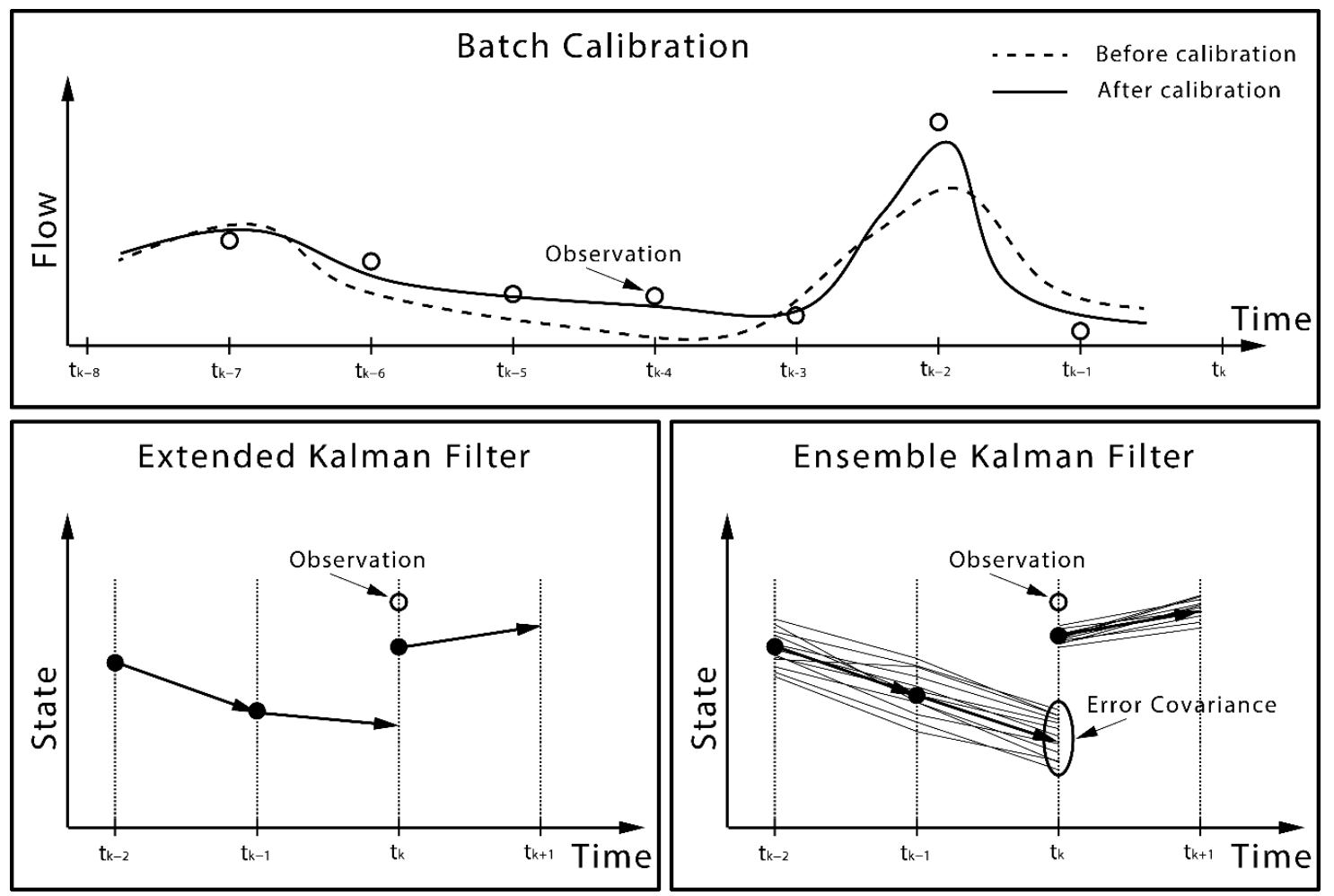

Figure 2. Schematic of exemplary approaches for data-model integration. $t_{k}$ represents the current time step.

\section{Remotely Sensed Precipitation}

Forecasts of future floods are subject to uncertainties from model structure, model parameters, initial conditions, and forecasted forcing. Although precipitation is the most important forcing for rainfall-runoff models, remotely sensed precipitation cannot be directly used in a forecasting model as it belongs to historical records. Currently, remotely sensed precipitation estimates are typically used as an alternative forcing for parameter estimation and model initialization so as to benefit flood forecasting. This section reviews current remotely sensed precipitation products and their implementation in flood forecasting applications.

\subsection{Overview of Products}

Rainfall is the most important forcing variable in rainfall-driven flood forecasting. There are three major sources of rainfall measurements: in-situ rain gauges, ground-based weather radar stations, and satellite retrievals [34]. Traditionally, hydrologic forecasting systems tend to rely on in-situ gauged rainfall. This technology has been proven to be a relatively accurate rainfall monitoring approach; however, the accuracy of rain gauge-based catchment precipitation estimates depends on the density and distribution of gauges and the uncertainty of the interpolation method. Recent development of remote sensing techniques has seen weather radar station and satellite-based precipitation become two important alternative rainfall sources [35,36].

A weather radar station (also called Doppler weather radar) is usually installed on the ground to continuously monitor the location, motion and type of precipitation. It is an active remote sensing technique which detects the radio reflectivity from target precipitation [36,37]. The radar reflectivity $(\mathrm{Z})$ is linked to rainfall rate $(R)$, which is known as Z-R relationship, to produce a quantitative precipitation estimation (QPE). It has been demonstrated that appropriate quantification of Z-R relationship can be essential for precipitation estimation [36,38,39]. Radar QPE commonly provides spatial data over areas of tens to hundreds kilometers in diameter with sub-hour temporal resolution and several kilometer 
spatial resolution. For instance, the US Next Generation Radar (NEXRAD) Weather Surveillance Radar-1988 Doppler (WSR-88D) provides up to $4 \mathrm{~km}$ spatial and 6 min temporal resolution QPE [36]. This makes up for the spatial poverty of gauged rainfall through radar-rain gauge fusion [37,40-45]. Although radar stations can provide relatively high spatiotemporal resolution QPE, a single station can only be suitable for small range applications. To extend the utility of radar QPE, large scale radar networks are gradually being established world-wide; e.g., the National Mosaic and Multi-Sensor QPE (NMQ) system in the USA [36].

The advances in satellite remote sensing have promoted the opportunity to continuously observe precipitation from space. The infrared and microwave remote sensing technologies have dominated satellite precipitation monitoring techniques. The thermal infrared (TIR) sensing has been used for rainfall monitoring since the 1970s, while the satellite microwave sensing of rainfall began during the 1980s [22]. The TIR remote sensors are typically installed on geostationary satellites, e.g., the Geostationary Operational Environmental Satellites (GOES), the European geostationary METEOrological SATellites (METEOSAT), the Multi-Function Transport Satellites (MTSAT), the Himawari geostationary weather satellites, and the Fengyun geostationary satellites, to detect brightness temperature of the cloud tops [46]. The precipitation is estimated based on the quantitative relationship between cloud-top temperature and rainfall rate, and that provides relatively good results for convective rainfall but is not satisfactory for stratiform rainfall [47]. As the TIR sensors are used in geostationary orbit, a constellation of satellites can yield continuous monitoring of precipitation with a coverage of the whole earth $\left(60^{\circ} \mathrm{N}-60^{\circ} \mathrm{S}\right)$. This is the major advantage of TIR rainfall sensing.

Both passive and active satellite microwave sensing techniques have been used for precipitation monitoring. Passive microwave sensors include the Tropical Rainfall Measuring Mission (TRMM) Microwave Imager (TMI) on TRMM, the Special Sensor Microwave/Imager (SSM/I) and the Special Sensor Microwave Imager/Sounder (SSMIS) on the Defense Meteorological Satellite Program (DMSP) satellites, Advanced Microwave Scanning Radiometer for the Earth Observing System (AMSR-E) on Aqua, the Advanced Microwave Sounding Unit (AMSU) on the National Oceanic and Atmospheric Administration (NOAA) satellites, and the Microwave Humidity Sounders (MHS) on later NOAA satellites and the European Operational Meteorological (MetOp) satellites [48]. Active microwave sensors include the Precipitation Radar (PR) on TRMM and the Radar on Global Precipitation Measurement (GPM) mission. Satellite microwave can obtain information throughout the clouds instead of the cloud-top, due to which the microwave precipitation can be more reliable and accurate. Microwave sensors are currently installed on low-orbit satellites, which limits the temporal resolution and spatial coverage [49]. Table 1 shows the basic parameters of different types of remote sensing precipitation.

Table 1. Remotely sensed precipitation techniques.

\begin{tabular}{|c|c|c|c|c|}
\hline Sensor Type & Platform Examples & $\begin{array}{l}\text { Horizontal } \\
\text { Resolution }\end{array}$ & Revisit & Accuracy \\
\hline Ground Radar & Ground stations & $10 \mathrm{~m}-1 \mathrm{~km}$ & $<10 \min$ (local) & High \\
\hline TIR & $\begin{array}{l}\text { TRMM, GOES, METEOSAT, } \\
\text { MTSAT, Himawari, Fengyun }\end{array}$ & $1-5 \mathrm{~km}$ & $30 \mathrm{~min}-3 \mathrm{~h}$ & Low \\
\hline Passive microwave & $\begin{array}{l}\text { GPM, TRMM, DMSP, Aqua, } \\
\text { NOAA, MetOp }\end{array}$ & $5-70 \mathrm{~km}$ & $3 \mathrm{~h}-1 \mathrm{~d}$ & High \\
\hline Satellite radar & GPM, TRMM & $\sim 5 \mathrm{~km}$ & $12 \mathrm{~h}-3 \mathrm{~d}$ & High \\
\hline
\end{tabular}

As a single satellite is limited in accuracy, coverage, and spatiotemporal resolution that can be achieved for hydrologic applications, a number of multi-satellite QPE algorithms have been developed, including:

- the Precipitation Estimation from Remote Sensing Information using Artificial Neural Networks (PERSIANN) [50]; 
- $\quad$ the PERSIANN-Cloud Classification System (PERSIANN-CCS) [51];

- the Self-Calibrating Multivariate Precipitation Retrieval (SCaMPR) [52];

- the combined Passive Microwave-Infrared (PMIR) algorithm [53];

- the Climate Prediction Center morphing approach (CMORPH) [46];

- the Naval Research Laboratory (NRL)-Blend Precipitation [54];

- $\quad$ the Global Satellite Mapping of Precipitation (GSMaP) [55];

- the TRMM Multi-satellite Precipitation Analysis (TMPA) [48]; and

- the Global Precipitation Measurement (GPM) mission [56].

These approaches integrate the advantages of TIR and microwave sensing techniques to generate global continuous satellite-based QPE products for either research (e.g., TMPA 3B42V7) or real-time operational (e.g., TMPA 3B42RT) applications [57].

\subsection{Implementation of Weather Radar Precipitation}

Since the ready availability of ground-based weather radar, a number of studies have been conducted to test the utility of radar QPE for hydrologic modelling. It has been demonstrated that radar QPE can be a useful forcing data for streamflow or flood predictions. The utility of radar QPE can be from several aspects. First, weather radar can provide a spatially distributed precipitation measurement, providing an important advantage over rain gauges, so that they can be easily adopted by distributed hydrologic models. For instance, Yang et al. [58] used weather radar observations for a continuous distributed hydrologic reservoir operation model for flood forecasting and control in the upper Tone River basin of Japan. Butts et al. [59] showed the use of radar QPE from NEXRAD in a distributed MIKE SHE hydrologic model and discussed the impact of rainfall forcing and model complexity on rapid flood forecasting. Kalinga and Gan [60] implemented radar QPE to a physically based semi-distributed model and tested the response in streamflow simulations. Cole and Moore [61] introduced both radar QPE and gauged rainfall into a distributed hydrologic model to forecast floods at gauged and ungauged areas. Islam and Gan [62] compared the use of NEXRAD precipitation data in semi-distributed and fully distributed models, and concluded that fully distributed models may make better use of distributed forcing information so as to make robust flow simulations.

Second, as weather radar stations measure precipitation under the clouds, it has a quick response to sudden and extreme storms; therefore, radar QPE have been used for extreme and flash flood forecasting. For instance, Vieux and Bedient [63] implemented radar precipitation for modelling an extreme meteorological and hydrologic event occurring on 17-18 October 1994 in South Texas, and illustrated that the Z-R relationship quantification can be critical for flood simulation. Gourley et al. [64] examined how commensurate today's high-resolution radar rainfall data is with flash flooding modelling at different scales. Javelle et al. [65] evaluated a flash flood warning system in two flood events using a radar-rain gauge fusion product. Morin and Yakir [66] illustrated how to use a high resolution radar to model the convective rain cells and the impacts on flash flood predictions in a semi-arid environment.

Third, weather radars provide additive value to rain gauges. It has been demonstrated that radar QPE can be a useful and reliable forcing for flood/streamflow forecasting in poorly gauged or ungauged regions $[61,65]$. For gauged areas, radar precipitation can be merged with gauged precipitation to generate a more accurate QPE product with a good spatiotemporal coverage and resolution, so as to benefit rainfall-runoff modelling and flood simulation [61,67-71].

Because of the limited footprint of a single weather station, early streamflow prediction applications were confined to small scale catchments [59,68]. Development of the radar network has brought the potential to use radar QPE for large scale applications closer to reality. For instance, Kitzmiller et al. [72] illustrated that the multiple NEXRAD mosaic QPE product could be used for streamflow simulations at large scales. Five weather stations were used for hydrologic prediction in 
Blue River Basin in Canada [60]. He et al. [73] combined with five weather radar stations to generate QPE to drive a hydrologic model which was implemented to the Skjern River Basin, Denmark.

\subsection{Implementation of Satellite Precipitation}

Satellite precipitation products have been an important source of forcing data for hydrologic modelling. The geostationary TIR satellites have been widely used for providing precipitation data to streamflow/flood simulations due to the continuous spatiotemporal coverage. For instance, METEOSAT TIR precipitation data have been implemented into a distributed hydrologic model (MIKE SHE) [74-76] and a simple lumped hydrologic model [77] for streamflow forecasting in the Senegal River Basin. It has been found that TIR precipitation generally results in reasonable flow simulation/forecasts for convective rainfall events, while there is a higher chance to get a poor flow simulation/forecast for stratiform rainfall events [74,77]. The microwave satellite precipitation have also drawn increasing attention in hydrologic modelling. For example, the precipitation estimates from Chinese meteorological satellite Fengyun-2C were tested in the Tarim River Basin for streamflow simulation with the distributed MIKE SHE model, and it has been found that microwave satellite provided relatively high spatial resolution precipitation in sparsely gauged areas which exhibited positive impact on flow simulation especially during summer time [78].

Beside the use of individual satellite precipitation products, there is an increasing interest in using multi-satellite QPEs. For instance, Hossain and Anagnostou [79] compared the TMI, SSM/I, and AMSR-E precipitation estimates, and tested the implementation of TMI, SSM/I, AMSR-E and TRMM IR precipitation estimates on streamflow prediction. Kalinga and Gan [80] developed an infrared-microwave rainfall algorithm (IMRA), which adjusts the QPE retrieved from the TRMM and GOES IR sensors with the TMI data, and applied it to the conceptual SACramento Soil Moisture Accounting (SAC-SMA) model. Since the launch of the TRMM, the TRMM rainfall products (e.g., TMPA) have been extensively implemented in streamflow/flood simulations [81-88]. Asante et al. [84] developed a linear geospatial streamflow simulation system using remotely sensed land and hydrologic inputs, including the TRMM precipitation product. Zulkafli et al. [89] conducted a comparative study on the performance of TRMM 3B42 Versions 6 and 7 in streamflow prediction. Kuligowski et al. [90] utilized TRMM data for flash flood forecasting. Beside the TRMM precipitation products, the SCaMPR [91] and the CMORPH [92] precipitation products have also been used for operational streamflow / flood forecasting. Recently, Jiang et al. [57] used multiple satellite precipitation products, including TMPA 3B42RT, PERSIANN, and CMORPH for ensemble streamflow simulation based on Bayesian Model Averaging (BMA). It has been found that multi-satellite QPEs generally provide more reliable and robust rainfall forcing for rainfall-runoff models than single satellite product $[72,77,91,92]$.

To combine the strength of satellite and gauged rainfall, the satellite-rain gauge precipitation estimates have also been implemented in streamflow/flood simulation. These applications include adjusting satellite QPE against gauged rainfall and implementing the QPE for streamflow simulation [93], interpolating gauged rainfall against the satellite precipitation pattern and using the interpolated rainfall for hydrologic prediction in data sparse regions [94].

\subsection{Challenges and Opportunities}

The rapid development in remote sensing techniques has promoted opportunities in monitoring rainfall using satellite and ground-based sensors and their application in flood forecasting. However, a number of challenges remain to be addressed, such as:

- large uncertainties in satellite-based and ground-radar precipitation estimates;

- developing a systematic guideline of choosing rainfall products and operational use of multiple source of information, e.g., gauged, satellite-based, and ground radar precipitations; and

- the use of remotely sensed precipitation for rainfall nowcast/forecast so as to drive flood forecasting. 
Various possible solutions have been proposed and tested in recent studies; however, there are still scientific and practical problems that need to be further addressed.

\subsubsection{Uncertainties in QPEs}

Although remote sensing techniques can provide spatially distributed precipitation estimates, there is no guarantee that reliable streamflow / flood simulations can be generated based on them, especially when compared to gauged rainfall records [74]. This relates to various sources of uncertainty in remote sensing data. When used as input data for rainfall-runoff models, the uncertainties from the remotely sensed precipitation will propagate through the model dynamics, which can considerably affect streamflow simulations $[95,96]$. Therefore, the questions of how to reduce the uncertainties in remotely sensed forcing and minimize the impact on streamflow simulations have been broadly explored but still remain a big challenge for the operational implementation of remote sensing precipitation for streamflow/flood forecasting.

Radar precipitation estimates are subject to uncertainties such as reflectivity calibration schemes, quantification of Z-R relationships, drop size, range degradation, and bright band contamination [96-99]. A series of efforts have been made to mitigate the uncertainties and the impacts on streamflow/flood simulation. One idea is to improve the precipitation estimation directly, e.g., to improve the identification of Z-R relationship and bright band so as to improve radar rainfall estimates and streamflow simulations [72]. Another solution, as mentioned before, is to reduce uncertainties in radar QPE by incorporating rain gauge records [37,40-45]. The radar-rain gauge merged QPEs can then be used for streamflow/flood modelling, and it has been found that these combined products generally result in an optimal streamflow prediction compared to the use of a single product $[61,68,69,72]$.

Satellite precipitation estimates usually contain significant systematic bias and random errors. Similar to radar uncertainty reduction studies, in addition to improving the sensing and retrieval techniques themselves, many efforts have been conducted in integrating different estimates to reduce uncertainties. As there are an increasing number of precipitation satellite products available, the first idea is to integrate multiple satellite estimates, which has promoted the growth of multi-satellite precipitation estimation algorithms and related products, such as TMPA and CMORPH mentioned above. Those multi-satellite blended products have been intensively used for hydrologic forcing $[81,88,90,92,100]$. To make a better use of those QPE products and further constrain the uncertainties, integrated use of multiple multi-satellite QPEs for streamflow simulation has been tested, and improved streamflow simulation has been demonstrated through multiple products ingestion [91] or Bayesian model averaging [57]. The second idea is the integrated use of satellite QPEs with gauged rainfall. One approach is to combine satellite QPE with gauged rainfall and then use the combined rainfall field as model forcing $[70,94]$. Another approach is to run the rainfall-runoff models separately using satellite and gauged precipitation estimates, and then combine the streamflow predictions through Bayesian model averaging [101]. The third idea is to correct precipitation errors during the hydrologic modelling processes through assimilation of other observations, e.g., satellite soil moisture [102-105] and gauged discharge [92], so as to enhance the streamflow predictability. The fourth idea is to produce precipitation from other satellite products. For instance, a new algorithm called SM2RAIN aimed to provide a new satellite precipitation product based only on satellite soil moisture observations using inverse modelling approaches [106-108].

\subsubsection{Operational Use of Multiple Products}

Decades of studies have provided a number of solutions for the integrated use of multiple information sources. However, when it comes to operational streamflow/flood forecasting practice, there are still questions to be investigated. First, what is the best way to fuse different data sources; blending the products first or running separate models and combine model outputs? To answer this question, comparative studies need to be conducted, not only to compare the simulation accuracy, 
but also the feasibility and efficiency for operational applications. Second, in practical situations there could be multiple sources of data sets, e.g., rain gauges, weather radar stations, satellite QPEs, discharge gauges, soil moisture observations, etc.; then how to use all available information in an integrated manner and how much impact introducing additional information will have on streamflow predictions need to be further explored. Third, a systematic guideline of choosing rainfall products and integration approaches for different situations needs to be established. For instance, the integrated use of both rain gauge and satellite precipitation can only be achieved in gauged regions $[70,94,101]$.

\subsubsection{Remotely Sensed Precipitation for Rainfall Forecast}

A good quality rainfall input dataset is essential for model structure identification, parameter estimation, and initial condition quantification. However, as mentioned before, the quality of remote sensing QPEs will not affect future flood forecasting directly, but through the model parameters and initial states. Nevertheless, there is also possibility to benefit rainfall forecasts from remote sensing techniques. For instance, the radar station can be used to generate rainfall field nowcasts $(<6 \mathrm{~h})$ by means of analogues (inferring from historical records), which can directly benefit flash flood forecasting [109]. Remotely sensed precipitation estimates can also be used to improve rainfall forecasts, e.g., assimilated into numerical weather prediction (NWP) models, to improve operational flood forecasting $[110,111]$. Those topics should draw more attention in the hydrologic forecasting community.

\section{Remotely Sensed Soil Moisture}

Remotely sensed soil moisture (RS-SM) has the potential to benefit flood forecasting through two approaches. Firstly, RS-SM can be included in model calibration so as to develop a more reliable parameter estimation, which can further benefit future forecasts. Secondly, soil moisture itself is an important initial condition for rainfall flood forecasting. It has been known that a different initial wetness of a catchment will lead to different runoff proportion for the same rainfall event. Therefore, RS-SM can be assimilated in real-time to reduce the uncertainty in model initial condition estimation. This section reviews current RS-SM products and their applications in model calibration and real-time updating.

\subsection{Overview of Products}

Soil moisture is a key variable in the earth system and plays an important role in hydrologic, meteorological and biologic processes [112]. Modern soil moisture monitoring technologies can be divided into in-situ techniques and remote sensing techniques. The early generation of in-situ monitoring techniques starts from the development of the neutron probe in the 1950s [113,114], which has been quickly commercialized and widely implemented [115]. In the 1980s, the application of in-situ soil moisture monitoring techniques was boosted by development of the time domain reflectometry (TDR) method, which uses the difference in dielectric properties of dry soil and water [116]. During the last couple of decades, further success has been achieved through the development of capacitance probes, heat dissipation and heat pulse sensors [115].

While in-situ probes provide continuous soil moisture measurements with a satisfactory level of accuracy, it has been widely admitted that these point measurements lack representativeness of regional soil water conditions [117]. Remote sensing techniques provide the opportunity to obtain spatial information on land surface soil moisture, compensating for the shortage of in-situ measuring techniques. Remote sensors such as microwave radiometers, scatterometers, synthetic aperture radar, optical and thermal infrared sensors, can be installed on towers, aircraft and satellites to obtain soil water information from a distance [115]. Satellite-based remote sensing provides continuous monitoring of the global soil moisture status, whilst aircraft-based remote sensing can be used to obtain regional soil moisture with higher resolution, which provides validation data for satellite-based soil moisture images. 
Microwave remote sensing for soil moisture has experienced a rapid development and wide application during the last couple of decades. A number of microwave soil moisture monitoring missions have been launched. One group of missions are based on the passive microwave sensing techniques, which receive natural microwave emissions from the land surface and retrieve soil moisture information based the dielectric impact on soil emissivity. These missions provide high accuracy and temporal repeat but low spatial resolution products. This group includes the Advanced Microwave Scanning Radiometer-Earth Observing System (AMSR-E) on the Aqua satellite [118], the Microwave Imaging Radiometer with Aperture Synthesis (MIRAS) on the European Space Agency Soil Moisture and Ocean Salinity (SMOS) satellite [119], and the AMSR-2 on the newly launched Global Change Observation Mission-Water "SHIZUKU" (GCOM-W1) [120]. The other group of missions are based on the active microwave sensing technique, which sends a microwave signal and retrieves soil moisture information through the backscatter signal strength related to soil dielectric constant and surface roughness. These missions provide high resolution but low accuracy and temporal repeat products. This group includes the Synthetic Aperture Radar (SAR) and Scatterometer (SCAT) on the European Space Agency Remote Sensing Satellite (ERS) [121], the Advanced Scatterometer (ASCAT) on the Meteorological Operational Satellite (Metop) [122].

Additionally, there are passive-active microwave missions, such as the Soil Moisture Active Passive (SMAP) mission launched in early 2015 [123]. Unfortunately, active radar on SMAP stopped working on 7 July 2015. Table 2 summarizes the main satellite-based passive and active microwave sensors used for soil moisture retrievals.

Table 2. Satellite-based microwave remote sensing for soil moisture monitoring.

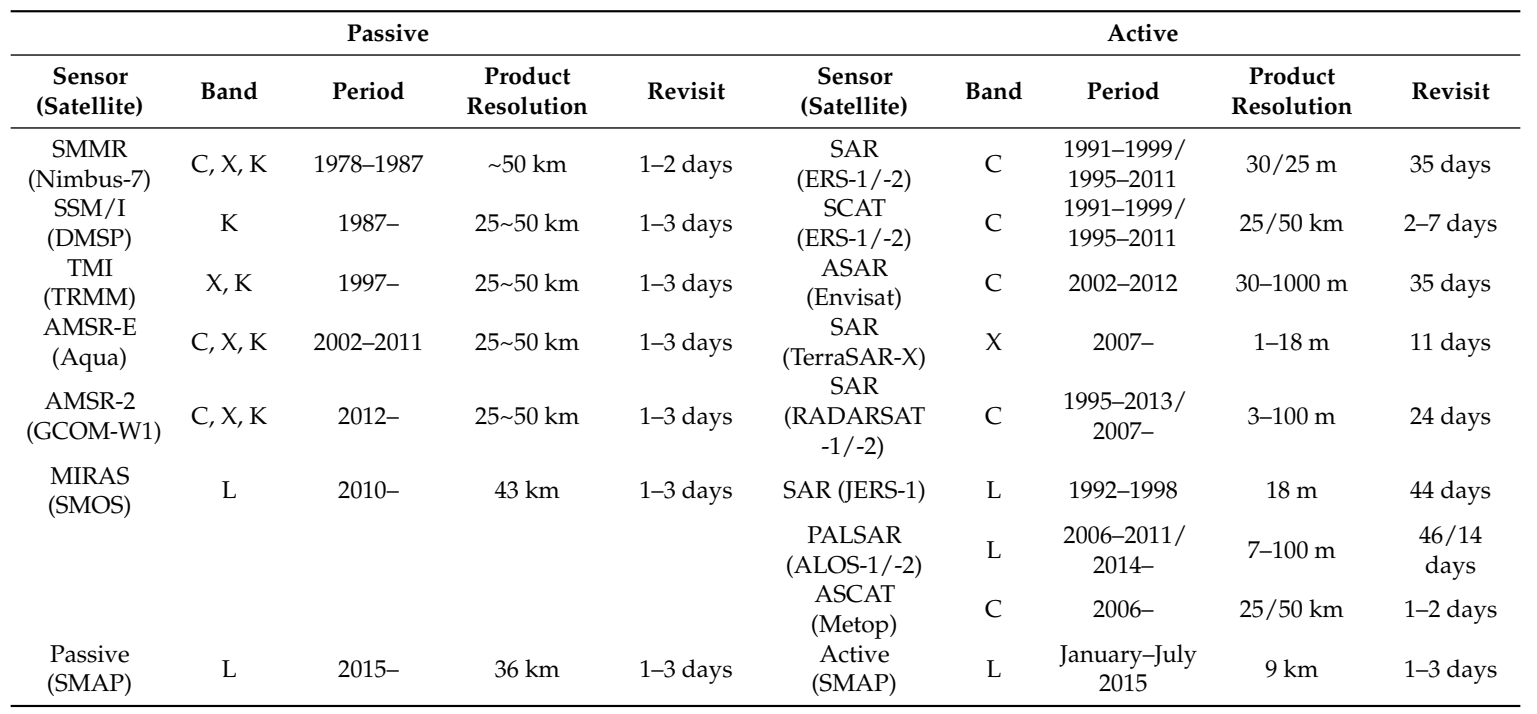

Signals detected by remote sensors are only related to the near-surface soil moisture conditions. More specifically, the measuring depth of microwave sensors is only about $3-5 \mathrm{~cm}$ for L-band $(1-2 \mathrm{GHz})$ and 1-1.5 cm for $C$ to $X(4-12 \mathrm{GHz})$ bands on bare soil [119]. This challenges the application of RS-SM products for hydrological models, which take into account the catchment soil water conditions for both surface and deeper soil layers [124]. Microwave-retrieved soil moisture information is affected by vegetation cover and the significance of the vegetation effect increases with the increase of frequency. Therefore, L-band sensors (e.g., SMOS) are generally considered to provide more reliable measurements than the $C$ and $X$ bands sensors (e.g., AMSR-E) in vegetated regions [17]. Active microwave sensors based on SAR technologies are able to detect land surface information with a relatively fine spatial resolution (e.g., 3-1000 m), but the revisit period is relatively long (e.g., 24-46 days). The microwave active scatterometers and passive radiometers provide soil moisture information with a relatively coarse spatial resolution (e.g., 25-50 km) but a finer temporal resolution (1-3 days) [123]. Therefore, 
there is a need to combine the strengths of active and passive microwave techniques to monitoring surface soil moisture conditions, which has led to the development of SMAP mission, with the purpose of compromising accuracy and spatial resolution.

There are several recent review articles on soil moisture monitoring technology and products from different perspectives. Examples include reviews on the significance of soil moisture in atmospheric, geomorphic, hydrologic, and biologic cycles [112], local scale soil moisture monitoring techniques [125], large scale soil moisture monitoring techniques [115,126], satellite-based soil moisture products [127], microwave remote sensing of soil moisture [128] and soil moisture downscaling approaches [129]. For more details on soil moisture remote sensing, it is recommended to refer to these review articles. There are also studies on the evaluation and comparison of advanced remote sensing soil moisture products [130-135], and these studies provide a better knowledge of quality, reliability and suitability of current remote sensing soil moisture products. The main focus of this section is the application of RS-SM products on flood/streamflow forecasting.

\subsection{Batch Calibration}

Operational flood forecasting models, including lumped, semi-distributed and distributed models, contain a number of parameters that can be highly conceptualized and are not directly measurable [136]. These parameters are traditionally estimated through minimizing the differences between observed and simulated streamflow in order to generate accurate and reliable future flow forecasts. The development of soil moisture monitoring techniques provides the potential to improve flood forecasting models through introducing additional information to further constrain the parameter estimation.

Including soil moisture into batch calibration can have a significant impact on parameter values $[137,138]$. It has been demonstrated that batch calibration using soil moisture can result in a better match between modelled and observed soil moisture [139]. However, these studies focused on improved surface or root-zone soil moisture simulation through either conceptual models or physically-based models [138,140-143]. From the flood forecasting perspective, a more important question is how the batch calibration using soil moisture affects the streamflow simulation/forecasting. Koren et al. [142] examined the effects on annual and monthly runoff by incorporating in-situ soil moisture into batch calibration. They found that adding soil moisture information into the batch calibration procedure can reduce soil moisture biases for both the surface and root-zone soil layers without a considerable reduction in the accuracy of the simulated runoff, implying better internal consistency of the batch calibration. However, as shown by Koren et al. [142], it is hard to get improvements in flow prediction by including soil moisture data in the batch calibration. This can be explained by the model structure, which has been developed to lead to optimal streamflow simulations. Soil moisture is not a physical variable in these models, but an intermediate model state variable. This lack of reality has impeded the development of soil moisture-based batch calibration approaches for flood forecasting.

In spite of the challenge in improving streamflow prediction by calibration using soil moisture, several explorations have been carried out recently $[136,144-147]$ to examine the potential of improving short-term streamflow forecasting by calibrating model parameters using soil moisture remote sensing data (Table 3). A relatively early study conducted by Parajka et al. [146] found that joint-calibration of a semi-distributed model using both streamflow and SAR/ERS derived soil moisture data improved the accuracy of the soil moisture predictions without degradation of the streamflow predictions. However, no obvious improvements were found at ungauged sub-catchments until a new modelling experiment was carried out [145], in which the improvements at ungauged sub-areas were identified under certain conditions. Nevertheless it was found that the joint calibration results in more robust calibration than the calibration using streamflow only case $[145,146]$. While studies by Parajka et al. $[145,146]$ used low temporal resolution SAR data in a semi-distributed system, further attention has been paid to calibrate fully distributed hydrologic models using higher temporal resolution microwave data [136,144,147]. Sutanudjaja et al. [144] used SCAT/ERS derived soil moisture data for a coupled groundwater-land 
surface model and found that the joint calibration using flow and soil moisture can reproduce good soil moisture and streamflow, as well as ground water head predictions. Wanders et al. [136] utilized AMSR-E, ASCAT and SMOS soil moisture data to calibrate a physically based model, with improved streamflow predictions obtained for the majority of the ungauged upstream regions. They also identified that the model benefitted most from the use of remote sensing data in areas with a lower density of discharge gauges.

While it is not guaranteed to achieve improvements in streamflow simulation/forecasting through accepting remotely sensed surface soil moisture information into the batch calibration, it is encouraging that RS-SM information results in a more robust parameter estimation [145]. It has been noted that multiple sub-optimal solutions can exist that all result in a similar model performance in highly nonlinear hydrological model batch calibration. Thus, one aspect of the improved robustness in batch calibration is to address the equifinality issue. This has been explored by Silvestro et al. [147], who tested the use of EUMETSAT soil moisture data to calibrate a distributed hydrologic model using the brute-force calibration algorithm. They demonstrated that some parameters are only weakly dependent on streamflow measurements, and that the use of both ground gauges and remote sensing data is able to additionally constrain the parameters and reduce the number of equifinal solutions. The improvement of the robustness and reduction in equifinality strengthen the reliability of the model predictions and raise the potential to improve flood forecasts in real-time scenarios.

Table 3. Studies calibrating a flood forecasting model using remotely sensed soil moisture data.

\begin{tabular}{|c|c|c|c|c|c|c|c|}
\hline Authors & Year & $\begin{array}{c}\text { Remote } \\
\text { Sensing Data }\end{array}$ & $\begin{array}{l}\text { Data } \\
\text { Period }\end{array}$ & Models & $\begin{array}{l}\text { Time } \\
\text { Scales }\end{array}$ & Algorithms & Study Basins \\
\hline $\begin{array}{c}\text { Parajka et al. } \\
\text { [146] }\end{array}$ & 2006 & $\begin{array}{c}\text { SAR } \\
\text { (ERS-1/-2) }\end{array}$ & 1992-2000 & $\begin{array}{c}\text { HBV } \\
\text { (Semi-distributed) }\end{array}$ & daily & SCE-UA & $\begin{array}{l}320 \text { Austrian } \\
\text { catchments }\end{array}$ \\
\hline $\begin{array}{c}\text { Parajka et al. } \\
\text { [145] }\end{array}$ & 2009 & $\begin{array}{c}\text { SAR } \\
(\text { ERS-1/-2) }\end{array}$ & 1992-2000 & $\begin{array}{c}\text { HBV } \\
\text { (Semi-distributed) }\end{array}$ & daily & SCE-UA & $\begin{array}{l}148 \text { Austrian } \\
\text { catchments }\end{array}$ \\
\hline $\begin{array}{l}\text { Wanders et al. } \\
\text { [136] }\end{array}$ & 2014 & $\begin{array}{l}\text { AMSR-E, } \\
\text { ASCAT and } \\
\text { SMOS }\end{array}$ & 2010-2011 & $\begin{array}{l}\text { LISFLOOD } \\
\text { (distributed) }\end{array}$ & daily & Dual EnKF & $\begin{array}{l}\text { Upper Danube } \\
\text { catchment, Europe }\end{array}$ \\
\hline $\begin{array}{c}\text { Sutanudjaja et al. } \\
\text { [144] }\end{array}$ & 2014 & $\begin{array}{c}\text { SCAT } \\
(\text { ERS-1/-2) }\end{array}$ & 1995-2000 & $\begin{array}{l}\text { PCR-GLOBWB-MOD } \\
\text { (distributed) }\end{array}$ & daily & Stepwise & $\begin{array}{c}\text { Rhine-Meuse basin, } \\
\text { Europe }\end{array}$ \\
\hline $\begin{array}{l}\text { Silvestro et al. } \\
\text { [147] }\end{array}$ & 2015 & EUMETSAT & 2006-2011 & $\begin{array}{l}\text { Continuum } \\
\text { (distributed) }\end{array}$ & hourly & Brute-force & $\begin{array}{l}\text { Orba basin and } \\
\text { Casentino basin, } \\
\text { Italy }\end{array}$ \\
\hline
\end{tabular}

\subsection{Data Assimilation}

Due to the important role of soil moisture in hydrologic, meteorological and ecological cycles, soil moisture data assimilation has received increasing attention, with plenty of studies published during the last one and a half decades. One group of studies, e.g., [148-178] assimilated soil moisture observations into land surface or soil moisture accounting models but their objectives were confined to improve soil moisture simulation/reanalysis. Another group of studies, e.g., [13,102-104,137,179-205] assimilated soil moisture observations into catchment hydrologic models aiming to update the initial conditions of a forecasting model so as to improve streamflow prediction/forecasts.

Among those soil moisture assimilation studies for streamflow forecasting, there is a small sub-class of studies that only examined the assimilation of in-situ soil moisture measurements [137,199-203]. Those studies provide a basic understanding of the impacts of integrating soil moisture information into streamflow / flood forecasting models on catchment hydrologic process modelling. The rest of the studies assimilated various RS-SM information into streamflow/flood forecasting models. There are a couple of studies [204,205] that only evaluated the impacts on antecedent soil moisture conditions. However, there has been an increasing interest in the impact of RS-SM assimilation on streamflow simulation, as summarized in Table 4. 
Table 4. Studies assimilating remotely sensed soil moisture data into flood forecasting models.

\begin{tabular}{|c|c|c|c|c|c|c|c|}
\hline Authors & Year & Remote Sensing Data & Data Period & Models & Time Scales & $\begin{array}{l}\text { Assimilation } \\
\text { Algorithms }\end{array}$ & Study Basins \\
\hline Goodrich et al. [193] & 1994 & Aircraft microwave SM & $07-08 / 1990$ & KINEROS (Semi-distributed) & daily & Direct insertion & Lucky-Hills-104 watershed, USA \\
\hline $\begin{array}{l}\text { Ottlé and } \\
\text { Vidal-Madjar [193] }\end{array}$ & 1994 & Infrared (NOAA-AVHRR) & 1985-1986 & Hydrological-SVA (Lumped) & daily & Direct insertion & Adour river catchment, France \\
\hline Loumagne et al. [13] & 2001 & SAR (ERS-1/-2) & $\begin{array}{l}\text { Not } \\
\text { provided }\end{array}$ & GRHUM (Lumped) & daily & KF & $\begin{array}{c}\text { Seine catchment upstream of } \\
\text { Paris, France; } \\
\text { Arade catchment in } \\
\text { southern Portugal }\end{array}$ \\
\hline Loumagne et al. [194] & 2001 & SAR (ERS-1/-2) & 1995-1997 & GRHUM (Lumped) & daily & Variational and EKF & $\begin{array}{l}\text { Seine catchment upstream of } \\
\text { Paris, France }\end{array}$ \\
\hline Quesney et al. [189] & 2001 & SAR (ERS-1/-2) & 1995-1997 & GRHUM (Lumped) & daily & EKF & The Orgeval river basin, France \\
\hline Pauwels et al. [179] & 2001 & SAR (ERS-1/-2) & 1995-1998 & TOPLATS (Lumped and semi-d) & hourly & $\begin{array}{l}\text { Nudging and statistic } \\
\text { correction }\end{array}$ & The Zwalm catchment, Belgium \\
\hline $\begin{array}{l}\text { Pauwels et al. [188] } \\
\text { Jacobs et al. [195] }\end{array}$ & $\begin{array}{l}2002 \\
2003\end{array}$ & $\begin{array}{l}\text { SAR (ERS-1/-2) } \\
\text { Aircraft microwave }\end{array}$ & $\begin{array}{c}1995-2000 \\
01-07 / 1997\end{array}$ & $\begin{array}{l}\text { TOPLATS (Lumped) } \\
\text { SCS (Empirical) }\end{array}$ & $\begin{array}{l}\text { hourly } \\
\text { daily }\end{array}$ & $\begin{array}{l}\text { Statistic correction } \\
\text { Statistic correction }\end{array}$ & $\begin{array}{l}\text { The Zwalm catchment, Belgium } \\
\text { The Little Washita Watershed, USA }\end{array}$ \\
\hline Aubert et al. [187] & 2003 & SAR (ERS-1/-2) & 1999-2000 & GR4J (Lumped) & daily & EKF & $\begin{array}{l}\text { Seine River basin, France; } \\
\text { Arade basin, Portugal }\end{array}$ \\
\hline Francois et al. [181] & 2003 & SAR (ERS-1) & 1995-1997 & GRKAL (Lumped) & daily & EKF & The Orgeval river basin, France \\
\hline Crow and Ryu [104] & 2009 & Synthetic SM & 1949-2003 & SAC-SMA (Lumped) & subdaily & EnKF, EnKS and KF & MOPEX basins, USA \\
\hline Brocca et al. [186] & 2010 & ASCAT & 2007-2009 & MISDc (Lumped) & hourly & Nudging & Upper Tiber river basin, Italy \\
\hline Draper et al. [197] & 2011 & ASCAT & 2007-2010 & SIM (Distributed) & sub-daily & EKF & France \\
\hline Chen et al. [196] & 2011 & Synthetic and ground SM & 2005-2008 & SWAT (semi-distributed) & daily & EnKF & Cobb Creek Watershed, USA \\
\hline Brocca et al. [191] & 2012 & ASCAT & 2007-2010 & $\begin{array}{l}\text { MISDc-2L two layer model } \\
\text { (Lumped) }\end{array}$ & hourly & EnKF & Upper Tiber river basin, Italy \\
\hline Han et al. [185] & 2012 & Synthetic SM & 2008-2009 & SWAT (Semi-distributed) & daily & EnKF & Upper Cedar Creek Watershed, USA \\
\hline Matgen et al. [184] & 2012 & ASCAT & 2007-2008 & BibModel (Lumped) & hourly & Particle filter & $\begin{array}{l}\text { Bibeschbach experimental catchment, } \\
\text { Grand Duchy of Luxembourg }\end{array}$ \\
\hline $\begin{array}{l}\text { Alvarez-Garreton et al. } \\
\qquad[180]\end{array}$ & 2014 & AMSR-E & 2002-2011 & PDM (Lumped) & daily & EnKF & Warrego River catchment, Australia \\
\hline Chen et al. [102] & 2014 & ASCAT and SMOS & 2010-2012 & SAC-SMA (Lumped) & subdaily & EnKF, EnKS and KF & 13 basins, central USA \\
\hline Ridler et al. [183] & 2014 & SMOS & $04-11 / 2010$ & $\begin{array}{l}\text { SW-ET-MIKE (Lumped and } \\
\text { semi-distributed) }\end{array}$ & daily & Bias-aware ETKF & $\begin{array}{l}\text { Ahlergaarde river basin, Western } \\
\text { Denmark }\end{array}$ \\
\hline Wanders et al. [182] & 2014 & $\begin{array}{l}\text { AMSR-E, ASCAT and } \\
\text { SMOS }\end{array}$ & $12-11 / 2011$ & LISFLOOD (Distributed) & daily & EnKF & $\begin{array}{l}\text { Upper Danube catchment upstream } \\
\text { of Bratislava, Europe }\end{array}$ \\
\hline Massari et al. [192] & 2014 & $\begin{array}{l}\text { ASCAT, AMSR-E and } \\
\text { ECMWF }\end{array}$ & 2009-2013 & SCRRM (Lumped) & hourly & Direct insertion & $\begin{array}{l}\text { Rafina river basin upstream from the } \\
\text { Rafina, Greece }\end{array}$ \\
\hline $\begin{array}{l}\text { Alvarez-Garreton et al. } \\
\qquad \text { [103] }\end{array}$ & 2015 & $\begin{array}{l}\text { AMSR-E, ASCAT and } \\
\text { SMOS }\end{array}$ & 2007-2014 & $\begin{array}{l}\text { PDM (Lumped and } \\
\text { semi-distributed) }\end{array}$ & daily & EnKF & Warrego River catchment, Australia \\
\hline Lievens et al. [198] & 2015 & SMOS & 2010-2011 & VIC (Distributed) & daily & EnKF & Murray-Darlin Basin, Australia \\
\hline
\end{tabular}




\subsubsection{The Development of Flood-Orientated RS-SM Assimilation Studies}

From the historical perspective of the literature, there are three stages of studies on flood-orientated RS-SM assimilation (Table 4 and Figure 3). Goodrich et al. [193] and Ottlé and Vidal-Madjar [190] were pioneers to integrate RS-SM data into catchment hydrologic modelling. Goodrich et al. [193] first used aircraft based microwave soil moisture data to initialize a semi-distributed flow forecasting model, while Ottlé and Vidal-Madjar [190] introduced infrared RS-SM (NOAA-AVHRR) to update a lumped hydrologic model. At that stage, the updating procedures were all performed through direct insertion, with both studies identifying that RS-SM information had impact on soil moisture simulation but no obvious improvement on runoff/streamflow.

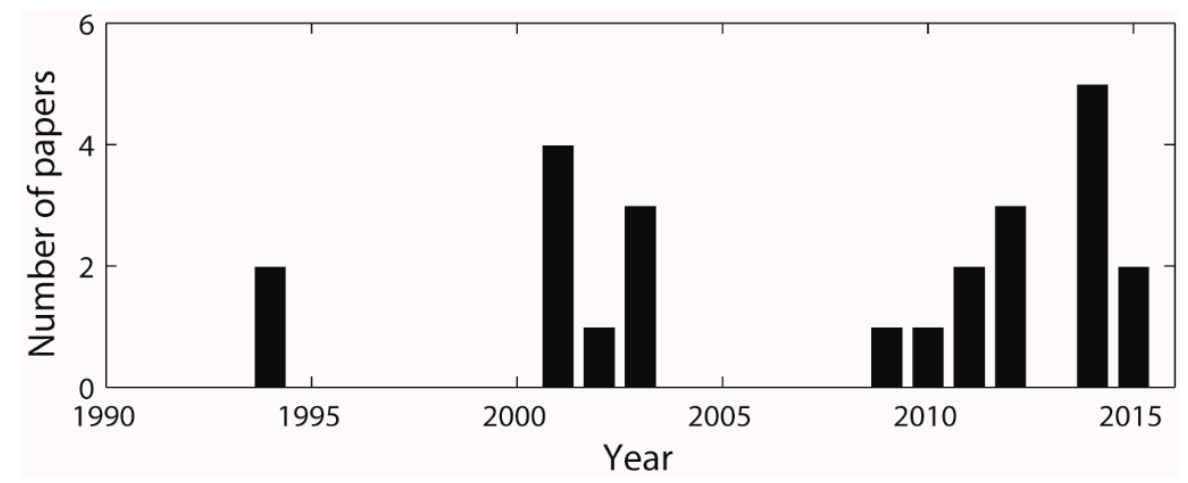

Figure 3. Number of papers published in each year from 1990-2015 on assimilating remotely sensed soil moisture data into flood forecasting models (calculated based on Table 4).

The second stage (2000-2003) is characterized by the use of ERS/SAR data (Table 4). The ERS satellite had a revisit period of 35 days. Therefore, not many RS-SM images could be used to update forecasting models. Empirical [195] and conceptual models [13,179,181,187-189,194] were the main focus at that stage. As it was not clear what type of data assimilation methods are most suitable for RS-SM assimilation during that period, various data assimilation approaches, including statistical correction [179,188,195], Newtonian nudging [179], variational data assimilation [194], the discrete Kalman filter (KF) [13] and the extended Kalman filter (EKF) $[181,187,189,194]$, were examined. Pauwels et al. $[179,188]$ did some comparison and found that statistical correction resulted in reliable updating of the forecasting models and there was no need to use nudging. It was gradually realized that Kalman filtering approaches are relatively strong in both uncertainty reduction ability and computational efficiency [181,187].

The third stage (2009-present) is characterized by the use of high temporal resolution RS-SM products (with revisits of 1-3 days). Beside a couple of tests using synthetic RS-SM data $[104,185,196]$, ASCAT [102,103,182,184,186,191,192,197], AMSR-E [103,180,182,192] and SMOS [102,103,182,183,198] soil moisture products were widely implemented during this period. Simultaneously assimilating multi-source RS-SM products has also been tested recently [102,103,182,192]. The choice of the data assimilation algorithm turned to be more consistent in this period. The majority of studies chose the ensemble Kalman filter (EnKF) [102-104,180,182,183,185,191,196,198], while just a few used nudging [186], hard updating [192] and EKF [197]. There were also few particle filter (PF) applications. An example is Matgen et al. [184]. However, the PF has not been widely implemented in flow / flood forecasting studies. One reason is that the PF can lead to ensemble collapse and needs to be resampled for ensemble forecasting, while the EnKF is more efficient to meet the operational requirement of low computational cost [206]. 


\subsubsection{Model Types for RS-SM Assimilation}

Streamflow forecasting models include purely empirical models, conceptual models and process-based models. From the spatial resolution perspective, empirical and conceptual models tend to be implemented in lumped or semi-distributed catchment systems. Process-based models calculate runoff generation and also spatial propagation of flows in a more physical manner, and are thus usually implemented in fully distributed catchment systems. Initially, lumped models were typically chosen [13,102-104,179-181,183,184,186-192,194,195]. A rainfall and soil moisture updating approach was tested by Crow and Ryu [104] in synthetic scenarios and further implemented by Chen et al. [102] in real RS-SM assimilation scenarios for a lumped system (SAC-SMA). Brocca et al. [186,191] examined the benefits of assimilating ASCAT-derived surface and root-zone soil moisture products through a simple lumped model (MISDc and MISDc-2L).

The operational forecasting systems, however, usually divide a forecasting catchment (especially for a large catchment) into a series of sub-catchments and link them through river routing models. Each sub-catchment is modelled through a lumped conceptual model and the whole system forms a semi-distributed model. With the development of flood forecasting and data assimilation techniques, there is an increasing need to adopt RS-SM assimilation approaches for semi-distributed models. Quite a few attempts have been carried out for semi-distributed model updating $[103,179,183,185,193,196]$, among which the challenges moving from lumped to semi-distributed models have also been explored $[103,183]$.

There was also distributed model updating work conducted in recent years [182,197,198]. It is noted that distributed models, e.g., grid-based, are able to benefit more from spatial soil moisture information provided by remote sensors. Besides, those models are more physically based and typically employ multiple soil layers, making them better suited to accept remotely sensed surface soil moisture information [183]. However, it also should be noted that most current operational flood forecasting systems still incorporate lumped and semi-distributed conceptual models because of their computational efficiency and the lack of spatially distributed data. Efforts to use operational lumped and semi-distributed model updating are still being made, although there are more challenges to use the spatially distributed remote sensing data [103].

It can also be inferred from Table 4 that more studies have focused on daily modelling time scale, with less implemented on hourly or sub-daily forecasting. Nevertheless, hourly forecasts have been widely adopted in operational forecasting applications, due to the demand of producing short-term forecasts from hours to several days. It can be more challenging to update an hourly model due to the lack of RS-SM samples, but it will also be quite beneficial if more attention is paid to this research area.

\subsubsection{Uncertainties Addressed in RS-SM Assimilation}

As soil moisture or soil water storages are key control variables in hydrologic models, it is a logical step to update soil moisture states through directly integrating RS-SM into the models. Addressing uncertainties in state variables can improve initial conditions of the model and in theory will benefit streamflow forecasts [182]. However, as most operational models are highly conceptualized, it is not promised that addressing errors in soil moisture states is the most beneficial approach to maximizing the benefit in streamflow forecasts. The examination of parameter updating $[13,194]$ has not attracted much attention, due to the indirect linkage between soil moisture data, parameters and flow predictions. Crow and Ryu [104] developed a dual updating approach to assimilate RS-SM data in order to simultaneously update input precipitation and catchment initial conditions (soil moisture and routing storages), with the approach examined through a set of synthetic experiments [104], further implemented by Chen et al. [196] for ground soil moisture assimilation, and later by Chen et al. [102] for the assimilation of ASCAT and SMOS soil moisture products. Some preliminary evidence has been provided showing that improved forcing is capable to bring additional benefits to soil moisture updating [102]. 


\subsubsection{Capability to Improve Flood Forecasting}

Assimilation of streamflow measurements generally brings direct improvements for streamflow estimation, as the assimilated observations are directly related to the predicted variables $[92,207,208]$. This is the major reason why streamflow data assimilation has been widely adopted for real-time forecasting. Nevertheless, it should be noted that state variables (e.g., soil moisture) are being updated through the assimilation of streamflow, which leads to a soil moisture estimate that results in the best streamflow simulation but does not necessarily correspond with the reality. Different from streamflow data assimilation, soil moisture affects the flow forecasts through the catchment hydrologic processes, which are typically not fully represented by forecasting models. Therefore, an obvious challenge is that improvement in soil moisture estimates does not necessarily lead to improvement in streamflow predictions. As indicated by most of the studies, soil moisture can be enhanced by integrating RS-SM data $[179,180,186,197]$, but the impact on streamflow forecasts varies. At an early stage, the potential to improve flood forecasts was identified by the assimilation of ERS/SAR products. However, the improvements were neither significant nor consistent for all conditions $[181,187,188,190,194]$. It was claimed that the low temporal frequency of the ERS satellites could be an important reason for the insufficient impacts on flow simulation $[187,188]$. This impeded the development of flood-oriented RS-SM assimilation from 2003 to 2009. Along with the development of high temporal resolution satellites, there was a broad testing of integrating ASCAT, AMSR-E and SMOS data since 2010. Brocca et al. [186] integrated ASCAT data for a simple conceptual model (MISDc) in the Upper Tiber River in central Italy, and found that improved runoff prediction can be obtained mainly when the initial soil wetness conditions are unknown. A follow up study by Brocca et al. [191] showed that the assimilation of root-zone soil moisture products has stronger impact than direct assimilation of surface soil moisture products on streamflow prediction. Draper et al. [197] found that the assimilation of ASCAT data improved the streamflow prediction to some extent, but the improvement may mainly result from the correction of large bias from precipitation, which was suggested to be addressed through bias-aware data assimilation approaches. Han et al. [185] found that the improvements in streamflow were much weaker than in soil moisture, and not consistent in all sub-areas. The study by Matgen et al. [184] illustrated that introducing soil moisture information brings limited or no extra improvement in streamflow prediction if the model is well calibrated by streamflow gauges. Alvarez-Garreton et al. $[103,180]$ applied RS-SM assimilation for both lumped and semi-distributed models, and a significant reduction of the ensemble spread was identified when using the EnKF. However, the NS efficiency of the mean prediction was not strongly improved. When RS-SM assimilation were performed in distributed models [182,198], improvements were identified especially in ungauged areas. However, negative results were also found by Ridler et al. [183], who showed that assimilation of SMOS soil moisture products resulted in overcorrection of errors in streamflow and flood peaks, which may be caused by the bias between observations and model estimates.

\subsection{Challenges and Opportunities}

While various RS-SM products have provided opportunities for addressing flood forecasting model uncertainties from different perspectives, e.g., improving the robustness of parameter estimation, updating the catchment initial wetness condition, and updating or retrieving antecedent rainfall to force the flood model, challenges come along with those opportunities. Brocca et al. [186] summarized the three main reasons that limited the benefits in streamflow prediction by integrating soil moisture data, including

- the spatial mismatch between the model and the remote sensing products;

- the different representativeness of the soil layers in the model; and

- remote sensing techniques, and limited data availability.

From the flood forecasting perspective, three important challenges should also be noted: 
- $\quad$ bias between remotely sensed and modelled soil moistures;

- error quantification for data assimilation; and

- the best strategy to optimally use multiple data sources to constrain the flood forecasting models.

\subsubsection{Representativeness of the Soil Layers}

One well-recognized challenge is how to propagate remotely sensed surface soil moisture information to the root-zone layer. This is not an issue for physically based models, as they typically employ multiple layers of soil moisture, in which the surface soil moisture in the model can be directly compared to the remote sensing products. However, it is a common issue in both batch calibration and data assimilation for conceptual forecasting models with a single soil water layer. One group of studies have used exponential filtering techniques to convert the remote sensing data to a root-zone soil wetness index $[103,147,180,186,191]$. This method is simple and easy to be implemented for all conceptual models. Another group of studies have addressed this issue by introducing a surface soil layer into conceptual models, such as the GRHUM [189,194], GRKAL [181] and MISDc-2L [191]. These approaches are model specific but more physically based. However, no comparison studies between these two approaches have yet been conducted.

\subsubsection{Bias between Remotely Sensed and Modelled Soil Moistures}

Even if the model has a surface layer, or the remotes sensing data have been converted to the root-zone layer, there may be significant bias between modelled and remotely sensed soil moisture. This can be a problem when stochastic data assimilation is implemented. First, significant bias violates the basic assumption of filtering approaches. Second, it may cause overcorrection of the soil moisture which leads to degradation in streamflow simulation. One solution is to perform bias-correction of the remote sensing data relative to the model, e.g., cumulative distribution function (CDF) matching $[103,144,180,186]$. This solution is effective for bias correction but the outcome is that all bias is attributed to the RS-SM data and the data will lose most of the information before they are assimilated into the model. This can lead to marginal impacts of RS-SM assimilation to streamflow prediction. Another approach is to calibrate the model against the RS-SM products, which can also remove most of the bias, and then perform data assimilation for the calibrated model $[136,182]$. This method seems to be effective but has not been widely implemented. It should be noted that both above solutions attribute all the bias either to the RS-SM data or the model itself. It has been suggested to incorporate online bias estimation and correction during data assimilation procedures. This is called bias-aware data assimilation, which still needs to be further examined [183,198,209-212].

\subsubsection{Error Quantification}

Error quantification is another important challenge in stochastic data assimilation. The efficiency of the widely implemented Kalman filtering and particle filtering approaches to a large extent depend on the reliability of the error assumption/estimation. Triple collocation has been widely used for quantifying uncertainties of RS products, but it requires three independent products to perform the procedure $[102,103,150,155]$. Adaptive filtering approaches have been introduced to estimate model and observational errors during the data assimilation process $[150,155,163]$, but have not been examined for flood modelling. Uncertainty quantification approaches, such as the Bayesian total error analysis (BATEA) [27,213], integrated Bayesian uncertainty estimator (IBUNE) [214], and the differential evolution adaptive metropolis (DREAM) algorithm [28], have been developed to disaggregate uncertainty to different sources, however, they also have not been widely tested for estimating RS-SM errors. One pioneering study by Alvarez-Garreton et al. [103] employed the maximum a posteriori estimation approach to quantify model and observational errors, which led to a reliable ensemble prediction; nevertheless, the impact on soil moisture assimilation and improvement in streamflow forecasts still needs to be further investigated [215]. 


\subsubsection{Strategy to Optimally Use Multiple Products}

While the improvements of flood forecasts using RS-SM products have not been generally proved, the RS-SM products continue to be increasingly available with the evolution of remote sensing techniques, as indicated in Table 2. Although in principle more information has the potential to facilitate a better forecasting model, there has not been a clear strategy to optimally fuse multiple products into forecasting models. Researches have been conducted in model calibration or updating using multiple RS-SM products since the recent couple of years [102,103,136,182,192]. It has been found that RS-SM products have different bias and error characteristics $[103,131,135]$. Possible solutions could be data pre-processing [215] or online processing [211]; nevertheless, great efforts are still needed to fully understand and address this practical challenge.

\section{Conclusions}

Remote sensing techniques for precipitation and soil moisture observation have undergone significant development in recent years. Ground-based weather radar, remote sensors based on geostationary satellites and microwave remote sensors based on polar orbit satellites have been widely used for precipitation monitoring. Moreover, various remote sensors, including microwave radiometers, scatterometers, synthetic aperture radar, optical, and thermal infrared sensors, installed on aircraft and satellites platforms, have been implemented to obtain land surface soil moisture information. Together, this has provided the opportunity to constrain hydrologic model input and state variables using remotely sensed precipitation and soil moisture products. Despite the large number of studies having been conducted to test the potential of using those remote sensing products for hydrologic modelling, the implementation for real-time forecasting is still under-researched and not widely adopted by operational sectors.

The advantage of providing spatially distributed rainfall fields has stimulated the interests in testing the potential of using radar and satellite precipitation estimates for rainfall-runoff modelling. However, this has not been widely adopted for operational practice due to uncertainty in the remote sensing products. Various methods have been proposed to reduce these uncertainties, e.g., fusing multiple remote sensing products, adjust remote sensing estimates using rain gauge measurements, and assimilating discharge or soil moisture data for input updating. Those studies have provided a scientific basis along with practical evidence to implement remote sensing precipitation for operational forecasting.

Recent advances in using RS-SM data for flood forecasting have provided evidence that the integration of remote sensing data with model predictions could lead to improved forecasts. However, this is not consistent since degradation and overcorrection were also reported in some cases. Those studies revealed a number of scientific and practical issues challenging the improvement in streamflow prediction, including the biases in remote sensing data and model states, the discrepancy between soil moisture depth in the model and the depth observed by remote sensing data, the lack of a physical relationship between soil moisture and streamflow in the model, and the differences in spatiotemporal scales between remote sensing data and modelled soil moisture. These issues are still under-researched and need to be further addressed before remote sensing data can be operationally implemented to constrain the flood forecasting models.

Currently, studies focus on testing the potential of improving streamflow prediction by using RS-SM products. However, this is a very practical objective which may not be achieved without addressing those aforementioned challenges. For instance, how to properly account for the model and observational biases along with the application of data assimilation and what will be the impact? What is the best way to propagate information from the surface layer to the root-zone layers and how much difference exists in terms of flow simulation among different methods? What is the best approach to use multiple remote sensing products to address uncertainties in different items, e.g., states, parameters and forcing data? It is important to understand whether and how much benefit can be achieved when 
each issue is addressed. There will be a greater potential to improve flood forecasting when better understanding and more effective solutions to those specific challenges are achieved.

With the development and maturation of remote sensing techniques, there are increasingly remotely sensed products available for use, and therefore further studies on how to optimally integrate multiple observations need to be conducted. Importantly, there is an increased collaboration between scientific and operational sectors to bring scientific achievements on remote sensing constrained flood forecasting into practice.

Acknowledgments: This study is financially supported by the Bushfires and Natural Hazards CRC project-Improving flood forecast skill using remote sensing data. Valentijn Pauwels is funded by ARC Future Fellow grant FT130100545. The authors acknowledge Australian Bureau of Meteorology and Geoscience Australia for their valuable suggestions and support. The authors would like to thank Ashley Wright from Monash University, the academic editor, and four reviewers for their valuable comments which improve the quality of this paper.

Author Contributions: The idea for the paper came from all authors. Yuan Li wrote the initial draft. Each co-author provided input based on their specific expertise, i.e., Valentijn R. N. Pauwels for the data-model integration techniques, Jeffrey P. Walker for the remote sensing, and Stefania Grimaldi for the flood modelling.

Conflicts of Interest: The authors declare no conflict of interest.

\section{References}

1. Sene, K. Flood Warning, Forecasting and Emergency Response; Springer: Berlin, Germany; London, UK, 2008.

2. Pagano, T.C.; Wood, A.W.; Ramos, M.-H.; Cloke, H.L.; Pappenberger, F.; Clark, M.P.; Cranston, M.; Kavetski, D.; Mathevet, T.; Sorooshian, S.; et al. Challenges of operational river forecasting. J. Hydrometeorol. 2014, 15, 1692-1707. [CrossRef]

3. Emerton, R.E.; Stephens, E.M.; Pappenberger, F.; Pagano, T.C.; Weerts, A.H.; Wood, A.W.; Salamon, P.; Brown, J.D.; Hjerdt, N.; Donnelly, C.; et al. Continental and global scale flood forecasting systems. Wiley Interdiscip. Rev. Water 2016, 3, 391-418. [CrossRef]

4. Werner, M.; Dijk, M.V. Developing flood forecasting systems: Examples from the UK, Europe, and Pakistan. In Proceedings of the ACTIF International Conference on Innovation Advances and Implementation of Flood Forecasting Technology, Tromsø, Norway, 17-19 October 2005.

5. Elliott, J.; Catchlove, R.; Sooriyakumaran, S.; Thompson, R. Recent advances in the development of flood forecasting and warning services in Australia. In Proceedings of the ACTIF International Conference on Innovation, Advances and Implementation of Flood Forecasting Technology, Tromsø, Norway, 17-19 October 2005.

6. Vehviläinen, B.; Huttunen, M.; Huttunen, I. Hydrological forecasting and real time monitoring in Finland: The watershed simulation and forecasting system (WSFS). In Proceedings of the ACTIF International Conference on Innovation Advances and Implementation of Flood Forecasting Technology, Tromsø, Norway, 17-19 October 2005.

7. Guan, H. Flood forecasting and management in China. In Proceedings of the ACTIF International Conference on Innovation Advances and Implementation of Flood Forecasting Technology, Tromsø, Norway, 17-19 October 2005.

8. Mcenery, J.; Ingram, J.; Duan, Q.; Adams, T.; Anderson, L. NOAA's advanced hydrologic prediction service: Building pathways for better science in water forecasting. Bull. Am. Meteorol. Soc. 2005, 86, 375-385. [CrossRef]

9. Alfieri, L.; Burek, P.; Dutra, E.; Krzeminski, B.; Muraro, D.; Thielen, J.; Pappenberger, F. GloFAS-Global ensemble streamflow forecasting and flood early warning. Hydrol. Earth Syst. Sci. 2013, 17, 1161-1175. [CrossRef]

10. Dewelde, J.; Verbeke, S.; Quintelier, E.; Cabus, P.; Vermeulen, A.; Vansteenkiste, T.; Jongh, I.D.; Cauwenberghs, K. Real-time flood forecasting system in Flanders. In Proceedings of the 11th International Conference on Hydroinformatics, New York, NY, USA, 17-21 August 2014.

11. Wang, Q.J.; Robertson, D.E.; Chiew, F.H.S. A Bayesian joint probability modeling approach for seasonal forecasting of streamflows at multiple sites. Water Resour. Res. 2009, 45, W05407. [CrossRef] 
12. Pietroniro, A.; Fortin, V.; Kouwen, N.; Neal, C.; Turcotte, R.; Davison, B.; Verseghy, D.; Soulis, E.D.; Caldwell, R.; Evora, N.; et al. Development of the MESH modelling system for hydrological ensemble forecasting of the Laurentian Great Lakes at the regional scale. Hydrol. Earth Syst. Sci. 2007, 11, 1279-1294. [CrossRef]

13. Loumagne, C.; Weisse, A.; Normand, M.; Riffard, M. Integration of remote sensing data into hydrological models for flood forecasting. In Remote Sensing and Hydrology 2000; IAHS Publication: Santa Fe, NM, USA, 2001; pp. 592-594.

14. Lettenmaier, D.P.; Alsdorf, D.; Dozier, J.; Huffman, G.J.; Pan, M.; Wood, E.F. Inroads of remote sensing into hydrologic science during the WRR era. Water Resour. Res. 2015, 51, 7309-7342. [CrossRef]

15. Liu, Y.; Weerts, A.H.; Clark, M.; Hendricks Franssen, H.J.; Kumar, S.V.; Moradkhani, H.; Seo, D.J.; Schwanenberg, D.; Smith, P.; van Dijk, A.I.J.M.; et al. Advancing data assimilation in operational hydrologic forecasting: Progresses, challenges, and emerging opportunities. Hydrol. Earth Syst. Sci. 2012, 16, 3863-3887. [CrossRef]

16. Montzka, C.; Pauwels, V.R.N.; Franssen, H.-J.; Han, X.; Vereecken, H. Multivariate and multiscale data assimilation in terrestrial systems: A review. Sensors 2012, 12, 16291-16333. [CrossRef] [PubMed]

17. $\mathrm{Xu}, \mathrm{X} . ; \mathrm{Li}, \mathrm{J} . ;$ Tolson, B.A. Progress in integrating remote sensing data and hydrologic modeling. Prog. Phys. Geogr. 2014, 38, 464-498. [CrossRef]

18. Dong, Q.; Zhan, C.; Wang, H.; Wang, F.; Zhu, M. A review on evapotranspiration data assimilation based on hydrological models. J. Geogr. Sci. 2016, 26, 230-242. [CrossRef]

19. Sun, L.; Seidou, O.; Nistor, I.; Liu, K. Review of the Kalman type hydrological data assimilation. Hydrol. Sci. J. 2016. [CrossRef]

20. Yan, K.; Di Baldassarre, G.; Solomatine, D.P.; Schumann, G.J.P. A review of low-cost space-borne data for flood modelling: Topography, flood extent and water level. Hydrol. Process. 2015, 29, 3368-3387. [CrossRef]

21. Musa, Z.N.; Popescu, I.; Mynett, A. A review of applications of satellite SAR, optical, altimetry and DEM data for surface water modelling, mapping and parameter estimation. Hydrol. Earth Syst. Sci. 2015, 19, 3755-3769. [CrossRef]

22. Gebremichael, M.; Hossain, F. Satellite Rainfall Applications for Surface Hydrology; Springer: Dordrecht, The Netherlands, 2010.

23. Tangdamrongsub, N.; Steele-Dunne, S.C.; Gunter, B.C.; Ditmar, P.G.; Weerts, A.H. Data assimilation of GRACE terrestrial water storage estimates into a regional hydrological model of the Rhine River basin. Hydrol. Earth Syst. Sci. 2015, 19, 2079-2100. [CrossRef]

24. Duan, Q.; Sorooshian, S.; Gupta, H.V. Effective and efficient global optimization for conceptual rainfall-runoff models. Water Resour. Res. 1992, 28, 1015-1031. [CrossRef]

25. Wang, Q.J. The genetic algorithm and its application to calibrating conceptual rainfall-runoff models. Water Resour. Res. 1991, 27, 2467-2471. [CrossRef]

26. Hendrickson, J.D.; Sorooshian, S.; Brazil, L.E. Comparison of Newton-type and direct search algorithms for calibration of conceptual rainfall-runoff models. Water Resour. Res. 1988, 24, 691-700. [CrossRef]

27. Kavetski, D.; Kuczera, G.; Franks, S.W. Bayesian analysis of input uncertainty in hydrological modeling: 1. Theory. Water Resour. Res. 2006, 42, W03407. [CrossRef]

28. Vrugt, J.A.; ter Braak, C.J.F.; Clark, M.P.; Hyman, J.M.; Robinson, B.A. Treatment of input uncertainty in hydrologic modeling: Doing hydrology backward with Markov chain Monte Carlo simulation. Water Resour. Res. 2008, 44, W00B09. [CrossRef]

29. Beven, K.; Binley, A. The future of distributed models: Model calibration and uncertainty prediction. Hydrol. Process. 1992, 6, 279-298. [CrossRef]

30. Moradkhani, H. Hydrologic remote sensing and land surface data assimilation. Sensors 2008, 8, $2986-3004$. [CrossRef]

31. Houser, P.R.; Reichle, R.H.; Walker, J.P. New technologies require advances in hydrologic data assimilation. EOS Trans. AGU 2003, 84, 545.

32. Walker, J.P.; Houser, P.R. Hydrologic Data Assimilation. In Advances in Water Science Methodologies; Aswathanarayana, A., Ed.; CRC Press: Leiden, The Netherlands, 2005. 
33. Moradkhani, H.; Sorooshian, S. General review of rainfall-runoff modeling: Model calibration, data assimilation, and uncertainty analysis. In Hydrological Modelling and the Water Cycle: Coupling the Atmosheric and Hydrological Models; Sorooshian, S., Hsu, K.L., Coppola, E., Tomassetti, B., Verdecchia, M., Visconti, G., Eds.; Springer: Berlin, Germany, 2008; Volume 63, pp. 1-24.

34. Michaelides, S.C. Precipitation: Advances in Measurement, Estimation and Prediction; Springer: Berlin, Germany, 2008.

35. Kidd, C.; Levizzani, V. Status of satellite precipitation retrievals. Hydrol. Earth Syst. Sci. 2011, 15, 1109-1116. [CrossRef]

36. Zhang, J.; Howard, K.; Langston, C.; Vasiloff, S.; Kaney, B.; Arthur, A.; Van Cooten, S.; Kelleher, K.; Kitzmiller, D.; Ding, F.; et al. National Mosaic and Multi-Sensor QPE (NMQ) system: Description, results, and future plans. Bull. Am. Meteorol. Soc. 2011, 92, 1321-1338. [CrossRef]

37. Krajewski, W.F. Cokriging radar-rainfall and rain gage data. J. Geophys. Res. Atmos. 1987, 92, 9571-9580. [CrossRef]

38. Libertino, A.; Allamano, P.; Claps, P.; Cremonini, R.; Laio, F. Radar estimation of intense rainfall rates through adaptive calibration of the Z-R relation. Atmosphere 2015, 6, 1559-1577. [CrossRef]

39. Xu, X.; Howard, K.; Zhang, J. An automated radar technique for the identification of tropical precipitation. J. Hydrometeorol. 2008, 9, 885-902. [CrossRef]

40. Yeung, H.Y.; Man, C.; Chan, S.T.; Seed, A. Development of an operational rainfall data quality-control scheme based on radar-raingauge co-kriging analysis. Hydrol. Sci. J. 2014, 59, 1293-1307. [CrossRef]

41. Bruno, F.; Cocchi, D.; Greco, F.; Scardovi, E. Spatial reconstruction of rainfall fields from rain gauge and radar data. Stoch. Environ. Res. Risk Assess. 2014, 28, 1235-1245. [CrossRef]

42. García-Pintado, J.; Barberá, G.G.; Erena, M.; Castillo, V.M. Rainfall estimation by rain gauge-radar combination: A concurrent multiplicative-additive approach. Water Resour. Res. 2009, 45, W01415. [CrossRef]

43. Goudenhoofdt, E.; Delobbe, L. Evaluation of radar-gauge merging methods for quantitative precipitation estimates. Hydrol. Earth Syst. Sci. 2009, 13, 195-203. [CrossRef]

44. Velasco-Forero, C.A.; Sempere-Torres, D.; Cassiraga, E.F.; Jaime Gómez-Hernández, J. A non-parametric automatic blending methodology to estimate rainfall fields from rain gauge and radar data. Adv. Water Resour. 2009, 32, 986-1002. [CrossRef]

45. Delrieu, G.; Bonnifait, L.; Kirstetter, P.-E.; Boudevillain, B. Dependence of radar quantitative precipitation estimation error on the rain intensity in the Cévennes region, France. Hydrol. Sci. J. 2014, 59, 1308-1319. [CrossRef]

46. Joyce, R.J.; Janowiak, J.E.; Arkin, P.A.; Xie, P. CMORPH: A method that produces global precipitation estimates from passive microwave and infrared data at high spatial and temporal resolution. J. Hydrometeorol. 2004, 5, 487-503. [CrossRef]

47. Ebert, E.E.; Janowiak, J.E.; Kidd, C. Comparison of near-real-time precipitation estimates from satellite observations and numerical models. Bull. Am. Meteorol. Soc. 2007, 88, 47-64. [CrossRef]

48. Huffman, G.J.; Bolvin, D.T.; Nelkin, E.J.; Wolff, D.B.; Adler, R.F.; Gu, G.; Hong, Y.; Bowman, K.P.; Stocker, E.F. The TRMM Multisatellite Precipitation Analysis (TMPA): Quasi-global, multiyear, combined-sensor precipitation estimates at fine scales. J. Hydrometeorol. 2007, 8, 38-55. [CrossRef]

49. Stephens, G.L.; Kummerow, C.D. The remote sensing of clouds and precipitation from space: A review. J. Atmos. Sci. 2007, 64, 3742-3765. [CrossRef]

50. Sorooshian, S.; Hsu, K.-L.; Gao, X.; Gupta, H.V.; Imam, B.; Braithwaite, D. Evaluation of PERSIANN system satellite-based estimates of tropical rainfall. Bull. Am. Meteorol. Soc. 2000, 81, 2035-2046. [CrossRef]

51. Hong, Y.; Hsu, K.-L.; Sorooshian, S.; Gao, X. Precipitation estimation from remotely sensed Imagery using an artificial neural network cloud classification system. J. Appl. Meteorol. 2004, 43, 1834-1853. [CrossRef]

52. Kuligowski, R.J. A self-calibrating real-time GOES rainfall algorithm for short-term rainfall estimates. J. Hydrometeorol. 2002, 3, 112-130.

53. Kidd, C.; Kniveton, D.R.; Todd, M.C.; Bellerby, T.J. Satellite rainfall estimation using combined passive microwave and infrared algorithms. J. Hydrometeorol. 2003, 4, 1088-1104. [CrossRef]

54. Turk, F.J.; Miller, S.D. Toward improved characterization of remotely sensed precipitation regimes with MODIS/AMSR-E blended data techniques. IEEE Trans. Geosci. Remote Sens. 2005, 43, 1059-1069. 
55. Kubota, T.; Shige, S.; Hashizume, H.; Aonashi, K.; Takahashi, N.; Seto, S.; Takayabu, Y.N.; Ushio, T.; Nakagawa, K.; Iwanami, K.; et al. Global precipitation map using satellite-borne microwave radiometers by the GSMaP project: Production and validation. IEEE Trans. Geosci. Remote Sens. 2007, 45, 2259-2275. [CrossRef]

56. Hou, A.Y.; Kakar, R.K.; Neeck, S.; Azarbarzin, A.A.; Kummerow, C.D.; Kojima, M.; Oki, R.; Nakamura, K.; Iguchi, T. The Global Precipitation Measurement Mission. Bull. Am. Meteorol. Soc. 2014, 95, 701-722.

57. Jiang, S.; Ren, L.; Hong, Y.; Yang, X.; Ma, M.; Zhang, Y.; Yuan, F. Improvement of multi-satellite real-time precipitation products for ensemble streamflow simulation in a middle latitude basin in south China. Water Resour. Manag. 2014, 28, 2259-2278.

58. Yang, D.; Koike, T.; Tanizawa, H. Application of a distributed hydrological model and weather radar observations for flood management in the upper Tone River of Japan. Hydrol. Process. 2004, 18, 3119-3132. [CrossRef]

59. Butts, M.; Overgaard, J.; Viaene, P.; Dubicki, A.; Stronska, K.; Szalinska, W.; Lewandowski, A.; Olszewski, T.; Kolerski, T. Flexible process-based hydrological modeling framework for flood forecasting-MIKE SHE. In Proceedings of the International Conference Innovation, Advances and Implementation of Flood Forecasting Technology, Tromsø, Norway, 17-19 October 2005.

60. Kalinga, O.A.; Gan, T.Y. Semi-distributed modelling of basin hydrology with radar and gauged precipitation. Hydrol. Process. 2006, 20, 3725-3746. [CrossRef]

61. Cole, S.J.; Moore, R.J. Distributed hydrological modelling using weather radar in gauged and ungauged basins. Adv. Water Resour. 2009, 32, 1107-1120. [CrossRef]

62. Islam, Z.; Gan, T. Hydrologic modeling of the Blue River Basin using NEXRAD precipitation data with a semidistributed and a fully distributed model. J. Hydrol. Eng. 2015, 20, 04015015. [CrossRef]

63. Vieux, B.E.; Bedient, P.B. Estimation of rainfall for flood prediction from WSR-88D reflectivity: A case study, 17-18 October 1994. Weather Forecast. 1998, 13, 407-415. [CrossRef]

64. Gourley, J.J.; Flamig, Z.L.; Hong, Y.; Howard, K.W. Evaluation of past, present and future tools for radar-based flash-flood prediction in the USA. Hydrol. Sci. J. 2014, 59, 1377-1389. [CrossRef]

65. Javelle, P.; Demargne, J.; Defrance, D.; Pansu, J.; Arnaud, P. Evaluating flash-flood warnings at ungauged locations using post-event surveys: A case study with the AIGA warning system. Hydrol. Sci. J. 2014, 59, 1390-1402. [CrossRef]

66. Morin, E.; Yakir, H. Hydrological impact and potential flooding of convective rain cells in a semi-arid environment. Hydrol. Sci. J. 2014, 59, 1353-1362. [CrossRef]

67. Sun, X.; Mein, R.G.; Keenan, T.D.; Elliott, J.F. Flood estimation using radar and raingauge data. J. Hydrol. 2000, 239, 4-18. [CrossRef]

68. Cole, S.J.; Moore, R.J. Hydrological modelling using raingauge- and radar-based estimators of areal rainfall. J. Hydrol. 2008, 358, 159-181. [CrossRef]

69. Biggs, E.M.; Atkinson, P.M. A comparison of gauge and radar precipitation data for simulating an extreme hydrological event in the Severn Uplands, UK. Hydrol. Process. 2011, 25, 795-810. [CrossRef]

70. Gourley, J.J.; Hong, Y.; Flamig, Z.L.; Wang, J.; Vergara, H.; Anagnostou, E.N. Hydrologic evaluation of rainfall estimates from radar, satellite, gauge, and combinations on Ft. Cobb Basin, Oklahoma. J. Hydrometeorol. 2011, 12, 973-988. [CrossRef]

71. Pan, T.-Y.; Li, M.-Y.; Lin, Y.-J.; Chang, T.-J.; Lai, J.-S.; Tan, Y.-C. Sensitivity analysis of the hydrological response of the Gaping River basin to radar-raingauge quantitative precipitation estimates. Hydrol. Sci. J. 2014, 59, 1335-1352. [CrossRef]

72. Kitzmiller, D.; Van Cooten, S.; Ding, F.; Howard, K.; Langston, C.; Zhang, J.; Moser, H.; Zhang, Y.; Gourley, J.J.; Kim, D.; et al. Evolving multisensor precipitation estimation methods: Their impacts on flow prediction using a distributed hydrologic model. J. Hydrometeorol. 2011, 12, 1414-1431. [CrossRef]

73. He, X.; Vejen, F.; Stisen, S.; Sonnenborg, T.O.; Jensen, K.H. An operational weather radar-based quantitative precipitation estimation and its application in catchment water resources modeling. Vadose Zone J. 2011, 10, 8-24. [CrossRef]

74. Andersen, J.; Dybkjaer, G.; Jensen, K.H.; Refsgaard, J.C.; Rasmussen, K. Use of remotely sensed precipitation and leaf area index in a distributed hydrological model. J. Hydrol. 2002, 264, 34-50. [CrossRef]

75. Stisen, S.; Sandholt, I. Evaluation of remote-sensing-based rainfall products through predictive capability in hydrological runoff modelling. Hydrol. Process. 2010, 24, 879-891. [CrossRef] 
76. Stisen, S.; Jensen, K.H.; Sandholt, I.; Grimes, D.I.F. A remote sensing driven distributed hydrological model of the Senegal River basin. J. Hydrol. 2008, 354, 131-148. [CrossRef]

77. Grimes, D.I.F.; Diop, M. Satellite-based rainfall estimation for river flow forecasting in Africa. I: Rainfall estimates and hydrological forecasts. Hydrol. Sci. J. 2003, 48, 567-584. [CrossRef]

78. Liu, T.; Willems, P.; Feng, X.W.; Li, Q.; Huang, Y.; Bao, A.M.; Chen, X.; Veroustraete, F.; Dong, Q.H. On the usefulness of remote sensing input data for spatially distributed hydrological modelling: Case of the Tarim River basin in China. Hydrol. Process. 2012, 26, 335-344. [CrossRef]

79. Hossain, F.; Anagnostou, E.N. Assessment of current passive-microwave- and infrared-based satellite rainfall remote sensing for flood prediction. J. Geophys. Res. Atmos. 2004, 109, D07102. [CrossRef]

80. Kalinga, O.A.; Gan, T.Y. Estimation of rainfall from infrared-microwave satellite data for basin-scale hydrologic modelling. Hydrol. Process. 2010, 24, 2068-2086. [CrossRef]

81. Xue, X.; Hong, Y.; Limaye, A.S.; Gourley, J.J.; Huffman, G.J.; Khan, S.I.; Dorji, C.; Chen, S. Statistical and hydrological evaluation of TRMM-based Multi-satellite Precipitation Analysis over the Wangchu Basin of Bhutan: Are the latest satellite precipitation products 3B42V7 ready for use in ungauged basins? J. Hydrol. 2013, 499, 91-99. [CrossRef]

82. Yong, B.; Hong, Y.; Ren, L.-L.; Gourley, J.J.; Huffman, G.J.; Chen, X.; Wang, W.; Khan, S.I. Assessment of evolving TRMM-based multisatellite real-time precipitation estimation methods and their impacts on hydrologic prediction in a high latitude basin. J. Geophys. Res. Atmos. 2012, 117, D09108. [CrossRef]

83. Su, F.; Hong, Y.; Lettenmaier, D.P. Evaluation of TRMM multisatellite precipitation analysis (TMPA) and its utility in hydrologic prediction in the La Plata Basin. J. Hydrometeorol. 2008, 9, 622-640. [CrossRef]

84. Asante, K.O.; Arlan, G.A.; Pervez, S.; Rowland, J. A linear geospatial streamflow modeling system for data sparse environments. Int. J. River Basin Manag. 2008, 6, 233-241. [CrossRef]

85. Khan, S.I.; Adhikari, P.; Hong, Y.; Vergara, H.; F Adler, R.; Policelli, F.; Irwin, D.; Korme, T.; Okello, L. Hydroclimatology of Lake Victoria region using hydrologic model and satellite remote sensing data. Hydrol. Earth Syst. Sci. 2011, 15, 107-117. [CrossRef]

86. Li, X.-H.; Zhang, Q.; Xu, C.-Y. Suitability of the TRMM satellite rainfalls in driving a distributed hydrological model for water balance computations in Xinjiang catchment, Poyang lake basin. J. Hydrol. 2012, 426-427, 28-38. [CrossRef]

87. Wagner, S.; Kunstmann, H.; Bárdossy, A.; Conrad, C.; Colditz, R.R. Water balance estimation of a poorly gauged catchment in West Africa using dynamically downscaled meteorological fields and remote sensing information. Phys. Chem. Earth 2009, 34, 225-235. [CrossRef]

88. Alarcon, V.; Alcayaga, H.; Alvarez, E. Assimilation of TRMM Precipitation into a Hydrological Model of a Southern Andes Watershed, Computational Science and Its Applications_ICCSA 2015; Springer International Publishing: Cham, Switzerland, 2015; pp. 468-476.

89. Zulkafli, Z.; Buytaert, W.; Onof, C.; Manz, B.; Tarnavsky, E.; Lavado, W.; Guyot, J.L. A comparative performance analysis of TRMM 3B42 (TMPA) versions 6 and 7 for hydrological applications over AndeanAmazon River Basins. J. Hydrometeorol. 2014, 15, 581-592. [CrossRef]

90. Kuligowski, R.J.; Li, Y.; Zhang, Y. Impact of TRMM data on a low-latency, high-resolution precipitation algorithm for flash-flood forecasting. J. Appl. Meteorol. Climatol. 2013, 52, 1379-1393. [CrossRef]

91. Lee, H.; Zhang, Y.; Seo, D.-J.; Kuligowski, R.J.; Kitzmiller, D.; Corby, R. Utility of SCaMPR satellite versus ground-based quantitative precipitation estimates in operational flood forecasting: The effects of TRMM data Ingest. J. Hydrometeorol. 2014, 15, 1051-1069. [CrossRef]

92. Lee, H.; Zhang, Y.; Seo, D.-J.; Xie, P. Utilizing satellite precipitation estimates for streamflow forecasting via adjustment of mean field bias in precipitation data and assimilation of streamflow observations. J. Hydrol. 2015, 529, 779-794. [CrossRef]

93. Wilk, J.; Kniveton, D.; Andersson, L.; Layberry, R.; Todd, M.C.; Hughes, D.; Ringrose, S.; Vanderpost, C. Estimating rainfall and water balance over the Okavango River Basin for hydrological applications. J. Hydrol. 2006, 331, 18-29. [CrossRef]

94. Stisen, S.; Tumbo, M. Interpolation of daily raingauge data for hydrological modelling in data sparse regions using pattern information from satellite data. Hydrol. Sci. J. 2015, 60, 1911-1926. [CrossRef]

95. Moradkhani, H.; Hsu, K.; Hong, Y.; Sorooshian, S. Investigating the impact of remotely sensed precipitation and hydrologic model uncertainties on the ensemble streamflow forecasting. Geophys. Res. Lett. 2006, 33, L12401. [CrossRef] 
96. Borga, M. Accuracy of radar rainfall estimates for streamflow simulation. J. Hydrol. 2002, 267, $26-39$. [CrossRef]

97. Habib, E.; Aduvala, A.V.; Meselhe, E.A. Analysis of radar-rainfall error characteristics and implications for streamflow simulation uncertainty. Hydrol. Sci. J. 2008, 53, 568-587. [CrossRef]

98. Habib, E.; Malakpet, C.; Tokay, A.; Kucera, P. Sensitivity of streamflow simulations to temporal variability and estimation of Z-R relationships. J. Hydrol. Eng. 2008, 13, 1177-1186. [CrossRef]

99. Collier, C.G. On the propagation of uncertainty in weather radar estimates of rainfall through hydrological models. Meteorol. Appl. 2009, 16, 35-40. [CrossRef]

100. Li, Z.; Yang, D.; Hong, Y. Multi-scale evaluation of high-resolution multi-sensor blended global precipitation products over the Yangtze River. J. Hydrol. 2013, 500, 157-169. [CrossRef]

101. Jiang, S.; Ren, L.; Hong, Y.; Yong, B.; Yang, X.; Yuan, F.; Ma, M. Comprehensive evaluation of multi-satellite precipitation products with a dense rain gauge network and optimally merging their simulated hydrological flows using the Bayesian model averaging method. J. Hydrol. 2012, 452-453, 213-225. [CrossRef]

102. Chen, F.; Crow, W.T.; Ryu, D. Dual forcing and state correction via soil moisture assimilation for improved rainfall-runoff modeling. J. Hydrometeorol. 2014, 15, 1832-1848. [CrossRef]

103. Alvarez-Garreton, C.; Ryu, D.; Western, A.W.; Su, C.H.; Crow, W.T.; Robertson, D.E.; Leahy, C. Improving operational flood ensemble prediction by the assimilation of satellite soil moisture: Comparison between lumped and semi-distributed schemes. Hydrol. Earth Syst. Sci. 2015, 19, 1659-1676. [CrossRef]

104. Crow, W.T.; Ryu, D. A new data assimilation approach for improving runoff prediction using remotely-sensed soil moisture retrievals. Hydrol. Earth Syst. Sci. 2009, 13, 1-16. [CrossRef]

105. Crow, W.T.; van den Berg, M.J.; Huffman, G.J.; Pellarin, T. Correcting rainfall using satellite-based surface soil moisture retrievals: The Soil Moisture Analysis Rainfall Tool (SMART). Water Resour. Res. 2011, 47, W08521. [CrossRef]

106. Brocca, L.; Moramarco, T.; Melone, F.; Wagner, W. A new method for rainfall estimation through soil moisture observations. Geophys. Res. Lett. 2013, 40, 853-858. [CrossRef]

107. Brocca, L.; Ciabatta, L.; Massari, C.; Moramarco, T.; Hahn, S.; Hasenauer, S.; Kidd, R.; Dorigo, W.; Wagner, W.; Levizzani, V. Soil as a natural rain gauge: Estimating global rainfall from satellite soil moisture data. J. Geophys. Res. Atmos. 2014, 119, 5128-5141. [CrossRef]

108. Ciabatta, L.; Brocca, L.; Massari, C.; Moramarco, T.; Puca, S.; Rinollo, A.; Gabellani, S.; Wagner, W. Integration of satellite soil moisture and rainfall observations over the Italian territory. J. Hydrometeorol. 2015, 16, 1341-1355. [CrossRef]

109. Smith, P.J.; Panziera, L.; Beven, K.J. Forecasting flash floods using data-based mechanistic models and NORA radar rainfall forecasts. Hydrol. Sci. J. 2014, 59, 1403-1417. [CrossRef]

110. Moser, B.A.; Gallus, W.A.; Mantilla, R. An initial assessment of radar data assimilation on warm season rainfall forecasts for use in hydrologic models. Weather Forecast. 2015, 30, 1491-1520. [CrossRef]

111. Shahrban, M.; Walker, J.P.; Wang, Q.J.; Seed, A.; Steinle, P. An evaluation of numerical weather prediction based rainfall forecasts. Hydrol. Sci. J. 2016. [CrossRef]

112. Legates, D.R.; Mahmood, R.; Levia, D.F.; DeLiberty, T.L.; Quiring, S.M.; Houser, C.; Nelson, F.E. Soil moisture: A central and unifying theme in physical geography. Prog. Phys. Geogr. 2011, 35, 65-86. [CrossRef]

113. Evett, S.R. Exploits and endeavors in soil water management and conservation using nuclear techniques. In Proceedings of the an International Symposium, International Atomic Energy Agency, Vienna, Austria, 29 October-1 November 2001.

114. Gardner, W.; Kirkham, D. Determination of soil moisture by neutron scattering. Soil Sci. 1952, 73, $391-402$. [CrossRef]

115. Ochsner, T.E.; Cosh, M.H.; Cuenca, R.H.; Dorigo, W.A.; Draper, C.S.; Hagimoto, Y.; Kerr, Y.H.; Njoku, E.G.; Small, E.E.; Zreda, M. State of the art in large-scale soil moisture monitoring. Soil Sci. Soc. Am. J. 2013, 77, 1888-1919. [CrossRef]

116. Topp, G.C.; Davis, J.L.; Annan, A.P. Electromagnetic determination of soil water content: Measurements in coaxial transmission lines. Water Resour. Res. 1980, 16, 574-582. [CrossRef]

117. Crow, W.T.; Berg, A.A.; Cosh, M.H.; Loew, A.; Mohanty, B.P.; Panciera, R.; de Rosnay, P.; Ryu, D.; Walker, J.P. Upscaling sparse ground-based soil moisture observations for the validation of coarse-resolution satellite soil moisture products. Rev. Geophys. 2012, 50, RG2002. [CrossRef] 
118. Njoku, E.G.; Jackson, T.J.; Lakshmi, V.; Chan, T.K.; Nghiem, S.V. Soil moisture retrieval from AMSR-E. IEEE Trans. Geosci. Remote Sens. 2003, 41, 215-229. [CrossRef]

119. Barre, H.M.J.; Duesmann, B.; Kerr, Y.H. SMOS: The mission and the system. IEEE Trans. Geosci. Remote Sens. 2008, 46, 587-593. [CrossRef]

120. Imaoka, K.; Kachi, M.; Fujii, H.; Murakami, H.; Hori, M.; Ono, A.; Igarashi, T.; Nakagawa, K.; Oki, T.; Honda, Y.; et al. Global Change Observation Mission (GCOM) for monitoring carbon, water cycles, and climate change. IEEE Proc. 2010, 98, 717-734. [CrossRef]

121. Merzouki, A.; McNairn, H.; Pacheco, A. Mapping soil moisture using RADARSAT-2 data and local autocorrelation statistics. IEEE J. Sel. Top. Appl. Earth Obs. Remote Sens. 2011, 4, 128-137. [CrossRef]

122. Bartalis, Z.; Wagner, W.; Naeimi, V.; Hasenauer, S.; Scipal, K.; Bonekamp, H.; Figa, J.; Anderson, C. Initial soil moisture retrievals from the METOP-A Advanced Scatterometer (ASCAT). Geophys. Res. Lett. 2007, 34, L20401. [CrossRef]

123. Entekhabi, D.; Njoku, E.G.; O’Neill, P.E.; Kellogg, K.H.; Crow, W.T.; Edelstein, W.N.; Entin, J.K.; Goodman, S.D.; Jackson, T.J.; Johnson, J.; et al. The Soil Moisture Active Passive (SMAP) mission. IEEE Proc. 2010, 98, 704-716. [CrossRef]

124. Loumagne, C.; Chkir, N.; Normand, M.; OttlÉ, C.; Vidal-Madjar, D. Introduction of the soil/vegetation/ atmosphere continuum in a conceptual rainfall/runoff model. Hydrol. Sci. J. 1996, 41, 889-902. [CrossRef]

125. Romano, N. Soil moisture at local scale: Measurements and simulations. J. Hydrol. 2014, 516, 6-20. [CrossRef]

126. Robinson, D.A.; Campbell, C.S.; Hopmans, J.W.; Hornbuckle, B.K.; Jones, S.B.; Knight, R.; Ogden, F.; Selker, J.; Wendroth, O. Soil moisture measurement for ecological and hydrological watershed-scale observatories: A review. Vadose Zone J. 2008, 7, 358-389. [CrossRef]

127. Wang, L.; Qu, J. Satellite remote sensing applications for surface soil moisture monitoring: A review. Front. Earth Sci. China 2009, 3, 237-247. [CrossRef]

128. Shi, J.; Du, Y.; Du, J.; Jiang, L.; Chai, L.; Mao, K.; Xu, P.; Ni, W.; Xiong, C.; Liu, Q.; et al. Progresses on microwave remote sensing of land surface parameters. Sci. China Earth Sci. 2012, 55, 1052-1078. [CrossRef]

129. Lakshmi, V. Remote sensing of soil moisture. ISRN Soil Sci. 2013, 2013, 424178. [CrossRef]

130. Kim, S.; Liu, Y.Y.; Johnson, F.M.; Parinussa, R.M.; Sharma, A. A global comparison of alternate AMSR2 soil moisture products: Why do they differ? Remote Sens. Environ. 2015, 161, 43-62. [CrossRef]

131. Leroux, D.J.; Kerr, Y.H.; Al Bitar, A.; Bindlish, R.; Jackson, T.J.; Berthelot, B.; Portet, G. Comparison between SMOS, VUA, ASCAT, and ECMWF soil moisture products over four watersheds in U.S. IEEE Trans. Geosci. Remote Sens. 2014, 52, 1562-1571. [CrossRef]

132. Parinussa, R.M.; Yilmaz, M.T.; Anderson, M.C.; Hain, C.R.; de Jeu, R.A.M. An intercomparison of remotely sensed soil moisture products at various spatial scales over the Iberian Peninsula. Hydrol. Process. 2014, 28, 4865-4876. [CrossRef]

133. Rüdiger, C.; Calvet, J.-C.; Gruhier, C.; Holmes, T.R.H.; de Jeu, R.A.M.; Wagner, W. An intercomparison of ERS-Scat and AMSR-E soil moisture observations with model simulations over France. J. Hydrometeorol. 2009, 10, 431-447. [CrossRef]

134. van der Schalie, R.; Parinussa, R.M.; Renzullo, L.J.; van Dijk, A.I.J.M.; Su, C.H.; de Jeu, R.A.M. SMOS soil moisture retrievals using the land parameter retrieval model: Evaluation over the Murrumbidgee Catchment, southeast Australia. Remote Sens. Environ. 2015, 163, 70-79. [CrossRef]

135. Su, C.-H.; Ryu, D.; Young, R.I.; Western, A.W.; Wagner, W. Inter-comparison of microwave satellite soil moisture retrievals over the Murrumbidgee Basin, southeast Australia. Remote Sens. Environ. 2013, 134, 1-11. [CrossRef]

136. Wanders, N.; Bierkens, M.F.P.; de Jong, S.M.; de Roo, A.; Karssenberg, D. The benefits of using remotely sensed soil moisture in parameter identification of large-scale hydrological models. Water Resour. Res. 2014, 50, 6874-6891. [CrossRef]

137. Aubert, D.; Loumagne, C.; Oudin, L. Sequential assimilation of soil moisture and streamflow data in a conceptual rainfall-runoff model. J. Hydrol. 2003, 280, 145-161. [CrossRef]

138. Montzka, C.; Moradkhani, H.; Weihermüller, L.; Franssen, H.-J.H.; Canty, M.; Vereecken, H. Hydraulic parameter estimation by remotely-sensed top soil moisture observations with the particle filter. J. Hydrol. 2011, 399, 410-421. [CrossRef]

139. Bandara, R.; Walker, J.P.; Rudiger, C. Towards soil property retrieval from space: Proof of concept using in situ observations. J. Hydrol. 2014, 512, 27-38. [CrossRef] 
140. Lü, H.; Yu, Z.; Zhu, Y.; Drake, S.; Hao, Z.; Sudicky, E.A. Dual state-parameter estimation of root zone soil moisture by optimal parameter estimation and extended Kalman filter data assimilation. Adv. Water Resour. 2011, 34, 395-406. [CrossRef]

141. Santanello, J.A., Jr.; Peters-Lidard, C.D.; Garcia, M.E.; Mocko, D.M.; Tischler, M.A.; Moran, M.S.; Thoma, D.P. Using remotely-sensed estimates of soil moisture to infer soil texture and hydraulic properties across a semi-arid watershed. Remote Sens. Environ. 2007, 110, 79-97. [CrossRef]

142. Koren, V.; Moreda, F.; Smith, M. Use of soil moisture observations to improve parameter consistency in watershed calibration. Phys. Chem. Earth 2008, 33, 1068-1080. [CrossRef]

143. Salvucci, G.D.; Entekhabi, D. An alternate and robust approach to calibration for the estimation of land surface model parameters based on remotely sensed observations. Geophys. Res. Lett. 2011, 38, L16404. [CrossRef]

144. Sutanudjaja, E.H.; van Beek, L.P.H.; de Jong, S.M.; van Geer, F.C.; Bierkens, M.F.P. Calibrating a large-extent high-resolution coupled groundwater-land surface model using soil moisture and discharge data. Water Resour. Res. 2014, 50, 687-705. [CrossRef]

145. Parajka, J.; Naeimi, V.; Blöschl, G.; Komma, J. Matching ERS scatterometer based soil moisture patterns with simulations of a conceptual dual layer hydrologic model over Austria. Hydrol. Earth Syst. Sci. 2009, 13, 259-271. [CrossRef]

146. Parajka, J.; Naeimi, V.; Blöschl, G.; Wagner, W.; Merz, R.; Scipal, K. Assimilating scatterometer soil moisture data into conceptual hydrologic models at the regional scale. Hydrol. Earth Syst. Sci. 2006, 10, 353-368. [CrossRef]

147. Silvestro, F.; Gabellani, S.; Rudari, R.; Delogu, F.; Laiolo, P.; Boni, G. Uncertainty reduction and parameter estimation of a distributed hydrological model with ground and remote-sensing data. Hydrol. Earth Syst. Sci. 2015, 19, 1727-1751. [CrossRef]

148. Yin, J.; Zhan, X.; Zheng, Y.; Liu, J.; Hain, C.R.; Fang, L. Impact of quality control of satellite soil moisture data on their assimilation into land surface model. Geophys. Res. Lett. 2014, 41, GL060659. [CrossRef]

149. Reichle, R.H.; De Lannoy, G.M.; Forman, B.; Draper, C.S.; Liu, Q. Connecting satellite observations with water cycle variables through land data assimilation: Examples using the NASA GEOS-5 LDAS. Surv. Geophys. 2014, 35, 577-606. [CrossRef]

150. Crow, W.T.; van den Berg, M.J. An improved approach for estimating observation and model error parameters in soil moisture data assimilation. Water Resour. Res. 2010, 46, W12519. [CrossRef]

151. Draper, C.S.; Reichle, R.H.; De Lannoy, G.J.M.; Liu, Q. Assimilation of passive and active microwave soil moisture retrievals. Geophys. Res. Lett. 2012, 39, L04401. [CrossRef]

152. Flores, A.N.; Bras, R.L.; Entekhabi, D. Hydrologic data assimilation with a hillslope-scale-resolving model and L band radar observations: Synthetic experiments with the ensemble Kalman filter. Water Resour. Res. 2012, 48, W08509. [CrossRef]

153. Plaza, D.A.; De Keyser, R.; De Lannoy, G.J.M.; Giustarini, L.; Matgen, P.; Pauwels, V.R.N. The importance of parameter resampling for soil moisture data assimilation into hydrologic models using the particle filter. Hydrol. Earth Syst. Sci. 2012, 16, 375-390. [CrossRef]

154. Chirico, G.B.; Medina, H.; Romano, N. Kalman filters for assimilating near-surface observations into the Richards equation-Part 1: Retrieving state profiles with linear and nonlinear numerical schemes. Hydrol. Earth Syst. Sci. 2014, 18, 2503-2520. [CrossRef]

155. Crow, W.T.; Yilmaz, M.T. The Auto-Tuned Land Data Assimilation System (ATLAS). Water Resour. Res. 2014, 50, 371-385. [CrossRef]

156. Kumar, S.V.; Harrison, K.W.; Peters-Lidard, C.D.; Santanello, J.A.; Kirschbaum, D. Assessing the impact of L-band observations on drought and flood risk estimation: A decision-theoretic approach in an OSSE environment. J. Hydrometeorol. 2014, 15, 2140-2156. [CrossRef]

157. Holmes, T.R.H.; Crow, W.T.; De Jeu, R.A.M. Leveraging microwave polarization information for the calibration of a land data assimilation system. Geophys. Res. Lett. 2014, 41, 2014GL061991. [CrossRef]

158. Dumedah, G.; Walker, J.P. Intercomparison of the JULES and CABLE land surface models through assimilation of remotely sensed soil moisture in southeast Australia. Adv. Water Resour. 2014, 74, 231-244. [CrossRef]

159. Kumar, S.V.; Reichle, R.H.; Koster, R.D.; Crow, W.T.; Peters-Lidard, C.D. Role of subsurface physics in the assimilation of surface soil moisture observations. J. Hydrometeorol. 2009, 10, 1534-1547. [CrossRef] 
160. Kumar, S.V.; Sekhar, M.; Bandyopadhyay, S. Assimilation of remote sensing and hydrological data using adaptive filtering techniques for watershed modelling. Curr. Sci. 2009, 97, 1196-1202.

161. Draper, C.S.; Mahfouf, J.F.; Walker, J.P. An EKF assimilation of AMSR-E soil moisture into the ISBA land surface scheme. J. Geophys. Res. Atmos. 2009, 114, D20104. [CrossRef]

162. Wang, D.; Cai, X.M. Robust data assimilation in hydrological modeling-A comparison of Kalman and H-infinity filters. Adv. Water Resour. 2008, 31, 455-472. [CrossRef]

163. Reichle, R.H.; Crow, W.T.; Keppenne, C.L. An adaptive ensemble Kalman filter for soil moisture data assimilation. Water Resour. Res. 2008, 44, W03423. [CrossRef]

164. Crow, W.T.; Kustas, W.P.; Prueger, J.H. Monitoring root-zone soil moisture through the assimilation of a thermal remote sensing-based soil moisture proxy into a water balance model. Remote Sens. Environ. 2008, 112, 1268-1281. [CrossRef]

165. Merlin, O.; Chehbouni, A.; Boulet, G.; Kerr, Y. Assimilation of disaggregated microwave soil moisture into a hydrologic model using coarse-scale meteorological data. J. Hydrometeorol. 2006, 7, 1308-1322. [CrossRef]

166. Drusch, M.; Wood, E.F.; Gao, H. Observation operators for the direct assimilation of TRMM microwave imager retrieved soil moisture. Geophys. Res. Lett. 2005, 32, L15403. [CrossRef]

167. Reichle, R.H.; Walker, J.P.; Koster, R.; Houser, P.R. Extended versus ensemble Kalman filtering for land data assimilation. J. Hydrometeorol. 2002, 3, 728-740. [CrossRef]

168. Reichle, R.H.; Mclaughlin, D.B.; Entekhabi, D. Hydrologic data assimilation with the ensemble Kalman filter. Mon. Weather. Rev. 2002, 130, 103-114. [CrossRef]

169. Reichle, R.H.; McLaughlin, D.B.; Entekhabi, D. Variational data assimilation of microwave radiobrightness observations for land surface hydrology applications. IEEE Trans. Geosci. Remote Sens. 2001, 39, 1708-1718. [CrossRef]

170. Montaldo, N.; Albertson, J.D.; Mancini, M.; Kiely, G. Robust simulation of root zone soil moisture with assimilation of surface soil moisture data. Water Resour. Res. 2001, 37, 2889-2900. [CrossRef]

171. Houser, P.R.; Shuttleworth, W.J.; Famiglietti, J.S.; Gupta, H.V.; Syed, K.H.; Goodrich, D.C. Integration of soil moisture remote sensing and hydrologic modeling using data assimilation. Water Resour. Res. 1998, 34, 3405-3420. [CrossRef]

172. Reichle, R.H.; Entekhabi, D.; McLaughlin, D.B. Downscaling of radio brightness measurements for soil moisture estimation: A four-dimensional variational data assimilation approach. Water Resour. Res. 2001, 37, 2353-2364. [CrossRef]

173. Scipal, K.; Drusch, M.; Wagner, W. Assimilation of a ERS scatterometer derived soil moisture index in the ECMWF numerical weather prediction system. Adv. Water Resour. 2008, 31, 1101-1112. [CrossRef]

174. Qiu, J.; Crow, W.T.; Mo, X.; Liu, S. Impact of temporal autocorrelation mismatch on the assimilation of satellite-derived surface soil moisture retrievals. IEEE J. Sel. Top. Appl. Earth Obs. Remote Sens. 2014, 7, 3534-3542. [CrossRef]

175. Draper, C.S.; Mahfouf, J.F.; Walker, J.P. Root zone soil moisture from the assimilation of screen-level variables and remotely sensed soil moisture. J. Geophys. Res. Atmos. 2011, 116, D02127. [CrossRef]

176. Dumedah, G.; Walker, J.P.; Merlin, O. Root-zone soil moisture estimation from assimilation of downscaled Soil Moisture and Ocean Salinity data. Adv. Water Resour. 2015, 84, 14-22. [CrossRef]

177. Walker, J.P.; Willgoose, G.R.; Kalma, J.D. One-dimensional soil moisture profile retrieval by assimilation of near-surface observations: A comparison of retrieval algorithms. Adv. Water Resour. 2001, 24, 631-650. [CrossRef]

178. Walker, J.P.; Willgoose, G.R.; Kalma, J.D. One-dimensional soil moisture profile retrieval by assimilation of near-surface measurements: A simplified soil moisture model and field application. J. Hydrometeorol. 2001, 2, 356-373. [CrossRef]

179. Pauwels, V.R.N.; Hoeben, R.; Verhoest, N.E.C.; De Troch, F.P. The importance of the spatial patterns of remotely sensed soil moisture in the improvement of discharge predictions for small-scale basins through data assimilation. J. Hydrol. 2001, 251, 88-102. [CrossRef]

180. Alvarez-Garreton, C.; Ryu, D.; Western, A.W.; Crow, W.T.; Robertson, D.E. The impacts of assimilating satellite soil moisture into a rainfall-runoff model in a semi-arid catchment. J. Hydrol. 2014, 519, 2763-2774. [CrossRef]

181. Francois, C.; Quesney, A.; Ottlé, C. Sequential assimilation of ERS-1 SAR data into a coupled land surface-hydrological model using an extended Kalman filter. J. Hydrometeorol. 2003, 4, 473-487. [CrossRef] 
182. Wanders, N.; Karssenberg, D.; de Roo, A.; de Jong, S.M.; Bierkens, M.F.P. The suitability of remotely sensed soil moisture for improving operational flood forecasting. Hydrol. Earth Syst. Sci. 2014, 18, 2343-2357. [CrossRef]

183. Ridler, M.-E.; Madsen, H.; Stisen, S.; Bircher, S.; Fensholt, R. Assimilation of SMOS-derived soil moisture in a fully integrated hydrological and soil-vegetation-atmosphere transfer model in Western Denmark. Water Resour. Res. 2014, 50, 8962-8981. [CrossRef]

184. Matgen, P.; Fenicia, F.; Heitz, S.; Plaza, D.; de Keyser, R.; Pauwels, V.R.N.; Wagner, W.; Savenije, H. Can ASCAT-derived soil wetness indices reduce predictive uncertainty in well-gauged areas? A comparison with in situ observed soil moisture in an assimilation application. Adv. Water Resour. 2012, 44, 49-65. [CrossRef]

185. Han, E.; Merwade, V.; Heathman, G.C. Implementation of surface soil moisture data assimilation with watershed scale distributed hydrological model. J. Hydrol. 2012, 416-417, 98-117. [CrossRef]

186. Brocca, L.; Melone, F.; Moramarco, T.; Wagner, W.; Naeimi, V.; Bartalis, Z.; Hasenauer, S. Improving runoff prediction through the assimilation of the ASCAT soil moisture product. Hydrol. Earth Syst. Sci. 2010, 14, 1881-1893. [CrossRef]

187. Aubert, D.; Loumagne, C.; Oudin, L.; Le Hegarat-Mascle, S. Assimilation of soil moisture into hydrological models: The sequential method. Can. J. Remote Sens. 2003, 29, 711-717. [CrossRef]

188. Pauwels, V.R.N.; Hoeben, R.; Verhoest, N.E.C.; De Troch, F.P.; Troch, P.A. Improvement of TOPLATS-based discharge predictions through assimilation of ERS-based remotely sensed soil moisture values. Hydrol. Process. 2002, 16, 995-1013. [CrossRef]

189. Quesney, A.; Francois, C.; Ottlé, C.; Le Hegarat, S.; Loumagne, C.; Normand, M. Sequential assimilation of SAR/ERS data in a lumped rainfall-runoff model with an extended Kalman filter. In Proceedings of the Remote Sensing and Hydrology 2000, Santa Fe, NM, USA, April 2001; Owe, M., Braubaker, K., Ritchie, J., Rango, A., Eds.; pp. 495-497.

190. Ottlé, C.; Vidal-Madjar, D. Assimilation of soil moisture inferred from infrared remote sensing in a hydrological model over the HAPEX-MOBILHY region. J. Hydrol. 1994, 158, 241-264. [CrossRef]

191. Brocca, L.; Moramarco, T.; Melone, F.; Wagner, W.; Hasenauer, S.; Hahn, S. Assimilation of surface- and root-zone ASCAT soil moisture products into rainfall-runoff modeling. IEEE Trans. Geosci. Remote Sens. 2012, 50, 2542-2555. [CrossRef]

192. Massari, C.; Brocca, L.; Barbetta, S.; Papathanasiou, C.; Mimikou, M.; Moramarco, T. Using globally available soil moisture indicators for flood modelling in Mediterranean catchments. Hydrol. Earth Syst. Sci. 2014, 18, 839-853. [CrossRef]

193. Goodrich, D.C.; Schmugge, T.J.; Jackson, T.J.; Unkrich, C.L.; Keefer, T.O.; Parry, R.; Bach, L.B.; Amer, S.A. Runoff simulation sensitivity to remotely sensed initial soil water content. Water Resour. Res. 1994, 30, 1393-1405. [CrossRef]

194. Loumagne, C.; Normand, M.; Riffard, M.; Weisse, A.; Quesney, A.; HÉGarat-Mascle, S.L.; Alem, F. Integration of remote sensing data into hydrological models for reservoir management. Hydrol. Sci. J. 2001, 46, 89-102. [CrossRef]

195. Jacobs, J.M.; Myers, D.A.; Whitfield, B.M. Improved rainfall/runoff estimates using remotely sensed soil moisture. J. Am. Water Resour. Assoc. 2003, 39, 313-324. [CrossRef]

196. Chen, F.; Crow, W.T.; Starks, P.J.; Moriasi, D.N. Improving hydrologic predictions of a catchment model via assimilation of surface soil moisture. Adv. Water Resour. 2011, 34, 526-536. [CrossRef]

197. Draper, C.S.; Mahfouf, J.F.; Calvet, J.C.; Martin, E.; Wagner, W. Assimilation of ASCAT near-surface soil moisture into the SIM hydrological model over France. Hydrol. Earth Syst. Sci. 2011, 15, 3829-3841. [CrossRef]

198. Lievens, H.; Tomer, S.K.; Al Bitar, A.; De Lannoy, G.J.M.; Drusch, M.; Dumedah, G.; Hendricks Franssen, H.J.; Kerr, Y.H.; Martens, B.; Pan, M.; et al. SMOS soil moisture assimilation for improved hydrologic simulation in the Murray Darling Basin, Australia. Remote Sens. Environ. 2015, 168, 146-162. [CrossRef]

199. Shi, Y.; Davis, K.J.; Zhang, F.; Duffy, C.J.; Yu, X. Parameter estimation of a physically-based land surface hydrologic model using an ensemble Kalman filter: A multivariate real-data experiment. Adv. Water Resour. 2015, 83, 421-427. [CrossRef]

200. Brocca, L.; Melone, F.; Moramarco, T.; Singh, V.P. Assimilation of observed soil moisture data in storm rainfall-runoff modeling. J. Hydrol. Eng. 2009, 14, 153-165. [CrossRef] 
201. Lee, H.; Seo, D.-J.; Koren, V. Assimilation of streamflow and in situ soil moisture data into operational distributed hydrologic models: Effects of uncertainties in the data and initial model soil moisture states. Adv. Water Resour. 2011, 34, 1597-1615. [CrossRef]

202. Samuel, J.; Coulibaly, P.; Dumedah, G.; Moradkhani, H. Assessing model state and forecasts variation in hydrologic data assimilation. J. Hydrol. 2014, 513, 127-141. [CrossRef]

203. van Loon, E.E.; Troch, P.A. Tikhonov regularization as a tool for assimilating soil moisture data in distributed hydrological models. Hydrol. Process. 2002, 16, 531-556. [CrossRef]

204. Oudin, L.; Weisse, A.; Loumagne, C.; Le Hegarat-Mascle, S. Assimilation of soil moisture into hydrological models for flood forecasting: A variational approach. Can. J. Remote Sens. 2003, 29, 679-686. [CrossRef]

205. Brocca, L.; Melone, F.; Moramarco, T.; Morbidelli, R. Antecedent wetness conditions based on ERS scatterometer data. J. Hydrol. 2009, 364, 73-87. [CrossRef]

206. Li, Y.; Ryu, D.; Western, A.W.; Wang, Q.J.; Robertson, D.E.; Crow, W.T. An integrated error parameter estimation and lag-aware data assimilation scheme for real-time flood forecasting. J. Hydrol. 2014, 519, 2722-2736. [CrossRef]

207. Xie, X.; Meng, S.; Liang, S.; Yao, Y. Improving streamflow predictions at ungauged locations with real-time updating: Application of an EnKF-based state-parameter estimation strategy. Hydrol. Earth Syst. Sci. 2014, 18, 3923-3936. [CrossRef]

208. Li, Y.; Ryu, D.; Western, A.W.; Wang, Q.J. Assimilation of stream discharge for flood forecasting: Updating a semidistributed model with an integrated data assimilation scheme. Water Resour. Res. 2015, 51, 3238-3258. [CrossRef]

209. De Lannoy, G.J.M.; Houser, P.R.; Pauwels, V.R.N.; Verhoest, N.E.C. State and bias estimation for soil moisture profiles by an ensemble Kalman filter: Effect of assimilation depth and frequency. Water Resour. Res. 2007, 43, W06401. [CrossRef]

210. De Lannoy, G.J.M.; Reichle, R.H.; Houser, P.R.; Pauwels, V.R.N.; Verhoest, N.E.C. Correcting for forecast bias in soil moisture assimilation with the ensemble Kalman filter. Water Resour. Res. 2007, 43, W09410. [CrossRef]

211. Pauwels, V.R.N.; De Lannoy, G.J.M. Error covariance calculation for forecast bias estimation in hydrologic data assimilation. Adv. Water Resour. 2015, 86, 284-296. [CrossRef]

212. Pauwels, V.R.N.; De Lannoy, G.J.M.; Hendricks Franssen, H.J.; Vereecken, H. Simultaneous estimation of model state variables and observation and forecast biases using a two-stage hybrid Kalman filter. Hydrol. Earth Syst. Sci. 2013, 17, 3499-3521. [CrossRef]

213. Renard, B.; Kavetski, D.; Leblois, E.; Thyer, M.; Kuczera, G.; Franks, S.W. Toward a reliable decomposition of predictive uncertainty in hydrological modeling: Characterizing rainfall errors using conditional simulation. Water Resour. Res. 2011, 47, W11516. [CrossRef]

214. Ajami, N.K.; Duan, Q.; Sorooshian, S. An integrated hydrologic Bayesian multimodel combination framework: Confronting input, parameter, and model structural uncertainty in hydrologic prediction. Water Resour. Res. 2007, 43, W01403. [CrossRef]

215. Su, C.-H.; Ryu, D.; Crow, W.T.; Western, A.W. Stand-alone error characterisation of microwave satellite soil moisture using a Fourier method. Remote Sens. Environ. 2014, 154, 115-126. [CrossRef]

(C) 2016 by the authors; licensee MDPI, Basel, Switzerland. This article is an open access article distributed under the terms and conditions of the Creative Commons Attribution (CC-BY) license (http://creativecommons.org/licenses/by/4.0/). 